WPS2873

\title{
A little Engine that Could ...: Domestic Private Companies and Vietnam's Pressing Need for Wage Employment
}

\author{
Liesbet Steer \\ Markus Taussig
}

The World Bank, Vietnam

World Bank Policy Research Working Paper 2873, August 2002

The Policy Research Working Paper Series disseminates the findings of work in progress to encourage the exchange of ideas about development issues. An objective of the series is to get the findings out quickly, even if the presentations are less than fully polished. The papers carry the names of the authors and should be cited accordingly. The findings, interpretations, and conclusions expressed in this paper are entirely those of the authors. They do not necessarily represent the view of the World Bank, its Executive Directors, or the countries they represent. Policy Research Working Papers are available online at http://econ.worldbank.org. 


\begin{abstract}
Vietnam's young private sector is growing fast. Crucial to this growth has been a policy environment that increasingly recognizes the importance of private entrepreneurshipparticularly its potential to help address the country ${ }^{1}$ s pressing need for significantly increased wage employment creation. Expanding the benefits of private sector growth beyond urban centers out into the rural areas where most Vietnamese live-and where poverty and underemployment are heaviest-will require significantly increased information flows on what is working and what is not.

This paper presents an objective picture of Vietnam's emerging private sector, two years after initial implementation of the country's much praised Enterprise Law. The country's private companies are significantly better off than they were just a couple years earlier, when regional economic recession and stagnation on domestic policy reforms had brought development of the formal private sector to a near standstill. At the same time, the sector ${ }^{1}$ s small base means that its impressive rates of job creation still fall far short of matching the booming growth of the overall work force.

Information for this paper is based on data collected from Vietnam's General Office of Statistics, a small number of individual company case studies, and a national firm-level survey designed and implemented by the authors. Research for the paper revealed significant gaps in available private sector data and flaws in current data gathering methodologies-calling into question the ability of policy makers and advisors to understand rapid, ongoing economic developments and make appropriate and timely policy decisions. The authors hope that this paper can serve as a starting point and an impetus for more targeted research aimed at identifying and addressing specifc obstacles to sustainable and broad based job and wealth creation.
\end{abstract}




\section{TABLE OF CONTENTS}

Summary and Conclusions ..........................................................................1

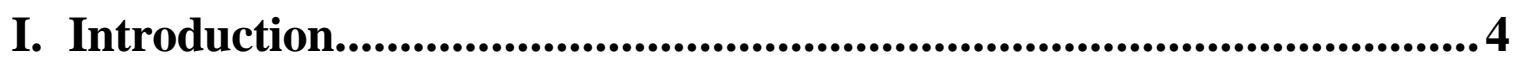

II. Defining the Domestic Formal Private Sector......................................6

III. Survey Objectives and Methodology ..................................................8

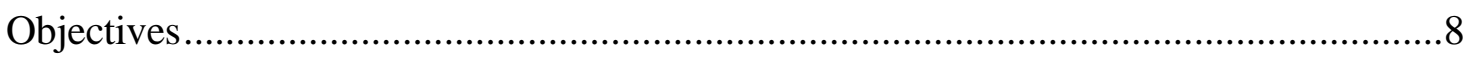

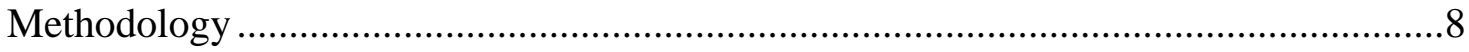

IV. The Current Picture: Vietnam's Private Companies in 2000 ..........9

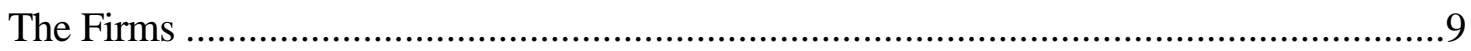

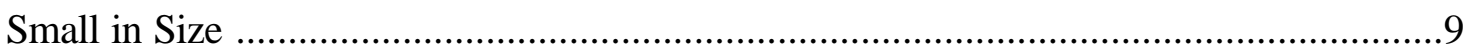

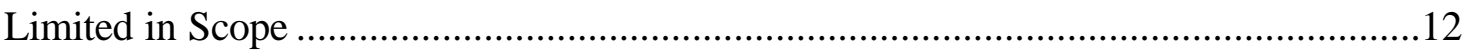

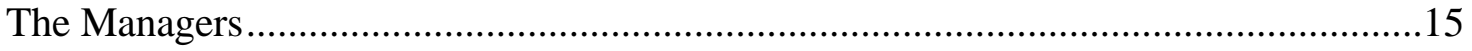

The Workers....................................................................................................

V. Trends ........................................................................................21

Is Formalization of Vietnam's Private Sector on the Rise? ........................................21

Is the Formal Private Sector Diversifying Geographically? .........................................24

Is the Formal Private Sector Increasing Its Activities in Export-oriented and Labor-

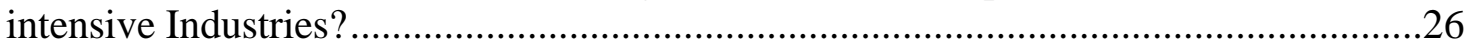

VI. Obstacles to Private Sector Growth .............................................30

Main Obstacles Identified in Earlier Studies …………………………………….......30

Are Key Obstacles to Further Private Sector Development Changing? ........................31

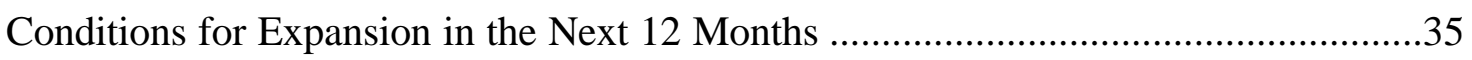

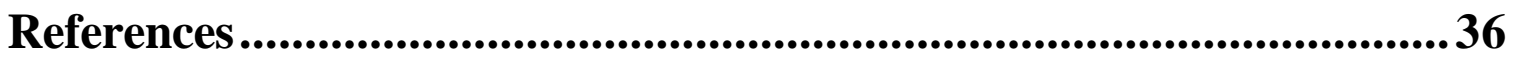




\section{ACKNOWLEDGEMENTS}

This report was commissioned by the World Bank and funded by DFID. Additional thanks go to Andrew Steer, Nisha Agrawal, and Rob Swinkels of the World Bank, Nguyen Dinh Cung of CIEM, Bob Warner of CIE, Sarah Bales, and Jed Friedman for their valuable comments on earlier drafts of the report.

\begin{tabular}{ll} 
& \multicolumn{1}{c}{ Abbreviations } \\
CIEM & Central Institute for Economic Management \\
DOLISA & Department of Labor, Invalids and Social Affairs \\
DPI & Department of Planning and Investment \\
GDP & Gross Domestic Product \\
GSO & General Statistics Office \\
ILSSA & The Institute for Labor Science and Social Affairs \\
MOLISA & Ministry of Labor, Invalids and Social Affairs \\
MPDF & Mekong Project Development Facility \\
MPI & Ministry of Planning and Investment \\
SME & Small and Medium Sized Enterprises \\
SOE & State Owned Enterprise \\
VAT & Value Added Tax
\end{tabular}




\section{SUMMARY AND CONCLUSIONS}

New growth in the private sector. Implementation of private sector reforms, highlighted by introduction of the Enterprise Law in January 2000, has introduced a new era for the formal private sector in Vietnam and provides hope in addressing Vietnam's pressing employment needs. By reducing the financial and time costs of registering companies, and by sending a positive message to entrepreneurs about the government's general attitude towards the private sector, the new law has led to a remarkable 35,440 registrations over its first two years - nearly two thirds the total number of registered firms for the entire preceding decade. 1 Preliminary evidence suggests that the increase in the number of genuinely active private companies has been between one third and one half of the number of new registrations.

The private sector picture remains mixed. The current picture shows the domestic formal private sector still dwarfed by both the state sector and the informal household economy. A more encouraging image emerges, however, when the focus is growth over time: private companies are not only creating more new wage jobs than any other economic sector, but are also drawing increasing volumes of investment and gaining increasing access to higher spending foreign markets. GDP effects of new registrations are likely to emerge over the next couple years.

The current base is still small... Domestic private companies' official shares of GDP and employment are eight and two percent, respectively. The capital-intensive state sector, in turn, represents a larger 30 percent of GDP and five percent of employment. Data on the private sector, however, are likely to somewhat under-represent the actual size of the private sector, as there are significant incentives for private companies to under-report both revenues and employment. Survey data gathered for this report indicates that employment in the domestic formal private sector would be more accurately reported at about three percent of total employment. Private sector activities are also concentrated in a limited number of industries. More than half of all domestic private companies are trade and retail service companies.

... but growing rapidly. The sudden jump in new registrations following the introduction of the Enterprise Law-as well as the improving business environment that supported it-is likely to speed up growth of private sector activities in the next few years. The private sector already contributed 15 percent to industrial growth between 1995 and 2000 — quite a substantial contribution given its small size. The freeing up of trading rights also led private exports to take off: 43 percent of export growth in 1999 and 2000 originated from the private sector.

Large growth in employment. The largest growth can be seen in employment. From 1996 to 2000, employment in the formal private sector more than doubled, creating more than three times as many new non-agricultural jobs as state enterprises and almost twice

\footnotetext{
${ }^{1}$ According to the latest figures available at the time of publishing for this report, registration of new companies in 2001 totalled 21,040 firms, with VND 26.5 trillion in registered capital (Statistics from Ministry of Planning and Investment, SME Department - supplied by the Central Institute for Economic Management). Corresponding figures for 2000 are 14,400 registrations and VND 13.9 trillion in capital. At publishing, CIEM had not yet resolved problems with province-by-province data, and therefore had not yet made that available.
} 
as many as the informal household sector. While confusion remains about official data, it appears new and existing private companies may have added nearly 250,000 new wage jobs in 2000 - a one-year increase of almost 45 percent. Survey findings indicate that at least another 50,000 seasonal or temporary jobs are likely to have been created, too. Given a significant further increase in registration numbers in 2001, it appears job creation by the private sector is very much on the rise. Increased private sector activity in labor-intensive and export-oriented industries holds out the promise that Vietnam's economy and its workers will benefit greatly from upcoming commitments for further trade liberalization.

The private sector attracts educated managers... There is reason to be encouraged by looking at who has been drawn into the domestic formal private sector. Firm managers are well-educated, with two thirds having graduated university. About three quarters are men and one quarter are women. Most owners did not own a business before but more than half have experience working in enterprises, mainly state enterprises.

..as well as educated workers. Workers are also surprisingly well-educated, reflecting not only Vietnam's strong human resource base but indicating that wage jobs with private companies are considered relatively attractive. While work in the domestic formal private sector comes with limited non-salary benefits, and almost half of the time does not come with a long-term contract, its popularity appears to reflect the fact that pay is still significantly higher and more stable than in the informal sector. The majority of workers are still recruited through informal channels, such as word of mouth through existing employees and family and friends.

Regional differences remain. The gap between Vietnam's North and South has decreased in recent years, but the South maintains a significant lead despite the significant formal education advantage held by managers and workers in the North. Ho Chi Minh City, in particular, remains far and above the leader of private sector activity in Vietnam. Generally speaking, differences between the most successful provinces and least successful provinces are increasing. More specifically, the gap between urban and rural private sector development is increasing. This may in part be inevitable, but there is reason to think Vietnam could learn from China's success in rural industrialization.

Obstacles to further growth. Entrepreneurs continue to feel that limited access to capital and excessive competition-whether from cheap imports or from favored state enterprises - are the main obstacles to business success. Difficulties regarding land and skilled labor seem to be growing in importance. Significant differences in development across provinces appears to indicate a significant role for local governance.

A final word on the data. This report was written to fill a void in the data available on private sector development and its impact on employment generation. Research for the report, however, found that data on the private sector is difficult to obtain, often varies according to government source, and is plagued by significant methodological inconsistencies-all detracting not only from the quality of economic research such as this report, but more importantly, from the ability of government to make informed, appropriate economic policy decisions. Good data is crucial to judging actual economic developments, including differences across sectors and regions, and judging the effectiveness of existing and planned public policy. Regular and reliable statistical 
updates on the private sector and its economic contribution are important inputs for policy makers at both the central and local levels - as well as for economic researchers with the ability to put forth policy recommendations. Therefore, donors and government should work together to address pressing issues regarding methodologies employed in statistics gathering, cooperation between government agencies, and the practice of regularly publishing and publicizing a full range of high-quality data. 


\section{INTRODUCTION}

1. Vietnam's work force will increase from 39 million to at least 50 million over the next decade. Over a million additional workers each year. Unemployment figures in Vietnam are already significant—particularly in urban areas.2 Underemployment in rural areas also remains a significant concern. For Vietnam's economic policy makers, the challenge is two-fold: not only to close the gap between supply and growing demand for jobs, but also to do so while continuing and building on the broad-based standard of living increases witnessed throughout the last decade. In other words, growth in both quantity and quality of employment.

2. The Vietnamese state and foreign-invested sectors-the country's two most important enterprise sectors in terms of contribution to GDP — are both primarily focused on capital-intensive projects and frequently aimed at domestic markets. As a result, neither has proven a significant source of new jobs. State enterprises, in particular, are presently more focused on increasing efficiency in order to deal with pressing issues such as non-performing commercial debt rather than on expanding their respective labor forces.

3. The domestic private sector is already Vietnam's leading employer. The vast majority of its jobs, however, are in agriculture or with household enterprises and do not provide workers with predictable wage incomes or other common benefits of formal employment such as pensions or insurance. Furthermore, jobs in the informal sector tend to generate minimal income for workers, as productivity is low. This is consistent with the experience of informal sectors in other developing countries. Neverthele ss, the two sectors do provide extremely important safety nets that fill in where the formal sector has failed to create more stable and secure wage jobs.

4. Vietnam's fastest growing source of relatively well-paid, relatively stable wage employment is its domestic private companies. While the domestic formal private sector remains small, Vietnam's government and donors increasingly see labor-intensive private companies as the key to addressing pressing employment and other social issues. The rationale is that capital constraints on Vietnam's private companies force them to be the formal enterprise sector most concentrated on Vietnam's comparative advantage of labor. Employment created per unit of investment in the private sector is significantly higher than in the state or foreign enterprise sectors. ${ }^{3}$

5. The apparent early success of the new Enterprise Law, in terms of the sudden increase in formally registered local private firms since implementation in January 2000, has fed optimism regarding domestic private companies' ability to fill the vacuum and produce much needed additional jobs. Information on actual developments regarding employment creation in the private sector, however, continues to be sparse and incomplete. This study gathers available macro-level facts and figures and supplements them with limited, targeted survey and case study research, while calling for greater focus on the quality and transparency of future statistics gathering, processing, and publication.

\footnotetext{
${ }^{2}$ In 2000, unemployment among people of working age in urban areas was 6.4 percent.

${ }^{3}$ CIEM/UNDP, "Domestic Private Sector Update: Improving Business Regulations and Regulatory Processes", June 2001, p. 13.
} 
6. The original aims of the study were to bring together available information on: (i) characteristics of private companies regarding sectoral activities, ownership, and location; (ii) the quantity and quality of employment in the private sector; (iii) the geographical distribution of private sector employment; and (iv) the potential for future growth in job creation. More specifically, study components include:

a. Descriptive macro-economic data on the private sector and employment. Previous research has shown that various ministries and organizations collect data on private enterprise-including the General Office of Statistics (GSO), Ministry of Planning and Investment (MPI), and Ministry of Labor, Invalids and Social Affairs (MOLISA), among others-but often data are inconsistent between sources. ${ }^{4}$ This report will look at different data, combining figures so as to create a general overview of the private sector and its impact on employment. The chief source of data is GSO, building on earlier statistics on the private sector and employment provided to the Mekong Project Development Facility (MPDF) in 1997 and 1998. ${ }^{5}$

b. A firm-level survey on the private sector and employment. The firm-level survey aims to confirm the picture of the private sector's role in job creation laid out by macro-level statistics and to supplement it through additional questions regarding hiring practices and obstacles to further growth. The survey was co-designed and co-implemented by the World Bank and the Institute for Labor Science and Social Affairs (ILSSA) under MOLISA. MPI's Central Institute for Economic Management (CIEM) assisted with provision of official lists of registered firms. See Section III for more on survey methodology and objectives.

c. Specific case studies of select private companies. The decision to also gather case studies was made in recognition of the fact that aggregate numbers may not fully communicate the job creation role of private companies. Case studies aim to add texture and understanding of the complexities behind macro-economic and survey figures. Areas of focus include the nature of the private sector employment (full time labor, casual labor, etc), the multiplier effect of private companies on employment through subcontracting, and employees' perspectives on the pros and cons of private sector employment. Core research for case studies was carried out by two independent Vietnamese consultants. Actual names of subjects are not used for any of the case studies.

7. The report begins by defining what exactly is meant by the domestic formal private sector. It then reviews the methodology employed to conduct the firm-level survey meant to supplement and check official statistics. Based on the data gathered from official sources and the survey, the report then presents a static view of the domestic formal private sector and its present employment creation role-aiming to give the reader a sense of the context in which current developments are occurring. The main issues and questions of the report are then addressed in the "Trends" section that follows. Finally,

\footnotetext{
${ }^{4}$ Steer, L. (2001). The private sector in Vietnam. Facts, figures, policy changes and a survey of research findings. Centre for International Economics, Canberra, Australia.

${ }^{5}$ Leila Webster and Markus Taussig (1999). Vietnam's Undersized Engine: A Survey of 95 Larger Manufacturers, MPDF Discussion Series, No. 8, June 1999.
} 
the report concludes with a section on obstacles to the further expansion of private sector development needed to meet Vietnam's pressing employment needs.

\section{DEFINING THE DOMESTIC FORMAL PRIVATE SECTOR}

8. The fundamental legal framework for what this report refers to as the domestic formal private sector was laid down in the early 1990s with Vietnam's Company Law (1990) and Law on Private Enterprises (1991). ${ }^{6}$ These laws established the legal basis for three forms of private companies: sole proprietorship, limited liability and shareholding companies. Both laws, however, lacked many of the facilities of a modern company law and burdened entrepreneurs with many restrictions and bureaucratic procedures. These problems, and the resulting stunted growth of the formal private sector, led to creation of the more comprehensive 1999 Enterprise Law. The new Enterprise Law expands the legal framework to cover household enterprises and introduces a new company form called a partnership. ${ }^{7}$

9. This report's definition of the domestic formal private sector includes the original three forms of private companies-sole proprietorships, limited liability and shareholding companies_and the newly added partnership form. ${ }^{8}$ Informal enterprises such as household enterprises are not included. Box 2.1 gives a summary of the four types of companies that define the domestic formal private sector. This distinction is important because studies and statistics on the private sector in Vietnam use a broad range of enterprise classifications. The result has been significant confusion in the private sector debate and inconsistency in data and analysis.

10. To illustrate, official statistics use the term non-state sector to include up to seven forms of private enterprises: four types of registered domestic private enterprises, as well as household firms, cooperatives and foreign invested enterprises. Official statistics also refer to the "private economy" (kinh te tu nhan), which includes only sole proprietorship companies, while limited liability and shareholding companies are presented separately under the vaguely- titled "mixed economy" (kinh te hon hop) category. 9 Official statistics on private companies are also very difficult to obtain and flawed by methodological inconsistencies. 10

11. Reports on the private sector, in turn, have not always distinguished between formal companies and household enterprises, sometimes referring to both as formal

\footnotetext{
${ }^{6}$ The legality of private enterprises was further strengthened by the Constitution in 1992, which recognized the right of freedom of business in various economic sectors, including the right to equal treatment among all economic sectors.

${ }^{7}$ Household enterprises were previously covered in a separate piece of legislation (Decree 66). Note that even though they are now included in the 1999 Enterprise Law, they are still subject to different regulations than formally registered enterprises. Household enterprises are now considered as "quasi-formal" private enterprises. They benefit from simple registration procedures but are restricted in certain business operations, such as the right to trade, scope of operation and land use rights. These restrictions are put in place to encourage household enterprises to become formal business entities. Household enterprises, however, do continue to enjoy significantly lower taxes as they do not pay VAT taxes and are in a better position to negotiate lower taxes with local officials.

${ }^{8}$ Also included is the newest form: a variation on the limited liability company that allows for single ownership unlike the original form that still is defined to include multiple owners.

${ }^{9}$ Webster and Taussig (1999), p. 13.

${ }^{10}$ The GSO's methods for calculating private sector statistics have varied across recent years. Methodologies appear to vary across provinces, too.
} 
companies and in other cases including both in analysis of the informal sector. The re is an argument to be made that many household enterprises no longer qualify as informal enterprises since they have been recognized and registered under the 1999 Enterprise Law. Furthermore, many household enterprises differ only from private companies in that authorities in their locality have not made efforts to bring them into the formal economy. Nevertheless, to ensure maximum clarity, this report chooses to keep household enterprises separate. Chief among reasons for doing so is the very different treatment informal enterprises receive from authorities and their inability to engage in certain business activities such as direct exporting. Collectives are also not included, despite sharing many similar operating features with private companies.

\section{Box 2.1 The Four Forms of Formal Domestic Private Companies}

Sole Proprietorship. A sole proprietorship has only one single owner who has unlimited liability for both business and non-business debts. Full liability matters less for such firms as they are small and rarely access bank financing, relying instead on savings and informal borrowing. Sole proprietorships also enjoy a special exemption from taxation during times of inactivity - a benefit of particular value for small firms in industries with seasonal fluctuations.

Limited Liability Company (with one or more owners). Limited liability companies come in two forms. The first form has only one owner, which must an organization, not an individual. The second, and more common, form is legally required to have two or more individuals as its owner. Owners' liability is limited to the owners' capital contributions. Financing can be obtained from family or banks (like sole proprietorship) but also by increasing capital through existing and new owners.

Shareholding Company. Shareholding companies have two or more owners. They have the same limited liability as Limited Liability companies but differ from the latter in a number of respects. First, they are unaffected by death or bankruptcy or withdrawal of the shareholder. Second, management is carried out by a Board of Management and Meeting of Shareholders. Apart from family, banks and owners, financing can also be obtained by issuing bonds or shares.

Partnership. This new form of private enterprise was introduced for the first time in the 1999 Enterprise Law. It offers an alternative to sole proprietorship in case there is more than one owner. Partners are unlimited and jointly liable for all obligations of the partnership. Liability of capital contributors is limited to the amount of capital contributed. Financing can be obtained through family and bank loans, capital mobilization through owners and issuing of bonds. This form has so far not proven very popular among entrepreneurs.

Source: CIEM (2001)

12. At present, Vietnam's domestic private sector is mainly composed of small and medium sized enterprises (SMEs). The average domestic private company employs 25 workers. The Vietnamese government defines SMEs as enterprises with a maximum capital of VND 5 billion and less than 200 employees (Document 681/CP-KTN). ${ }^{11}$ About 98 percent of domestic private companies in Vietnam fall into this category. While SMEs do indeed make up the greater part of the domestic private sector grouping that is the focus of this report, the report should not be seen to be speaking about issues

\footnotetext{
${ }^{11}$ Classification criteria regarding small and medium enterprises vary form country to country. Some criteria are based on number of employees, some are based on capital size and others use both employees and capital.
} 
specific to enterprises of any particular size grouping - but instead about issues specific to formally registered private companies.

\section{SURVEY OBJECTIVES AND METHODOLOGY}

\section{Objectives}

13. The firm-level survey conducted for this report provides complementary information that both supplements and serves as a check on official GSO data. The survey allowed testing of a hypothesis that official statistics underestimate labor in the domestic formal private sector. The survey further sought to update information on employment and related business information gathered by earlier private sector surveys, with an eye to seeing what changes may have occurred with the dramatic increase in private sector registrations since implementation of the new 1999 Enterprise Law.

\section{Methodology}

14. The Approach. The survey's target population of enterprises was Vietnam's formal domestic private sector-defined as all sole proprietorship firms, limited liability companies, joint-stock companies, and partnership companies registered under either the 1991 Company Law or 1999 Enterprises Law (See Section II). The survey randomly selected 200 manufacturing and construction firms and 200 service firms, with limits only on geographic location and not on firm size or activity. The decision to have a larger representation of industrial firms was based on these firms' role as the most prolific providers of jobs in the private sector.

15. The Population. The six provinces included in the survey were: Binh Duong, Ho Chi Minh City and Long An in the South, Hai Phong, Hanoi, and Ha Tay in the North. These provinces were chosen for three main reasons: i.) they host a high percentage of all private companies in Vietnam, particularly the larger manufacturers ${ }^{12}$ - allowing for both a study of success and a maximum efficiency with regard to implementation; ii.) they represented both North and South and urban and rural; and iii.) five of the six were surveyed in 1991 and 1997 by ILSSA and the Stockholm School of Economicsallowing comparison on some questions across years and for the survey to benefit from ILSSA's previous experience and contacts. Four of the six provinces were also included in the 1999 private sector survey by MPDF. Within each province/city, sample populations were further limited to two districts that were seen together to be reasonably representative of the whole province/city.

16. Lists of registered firms for each district were provided by local Departments of Planning and Investment (DPI) offices through CIEM. DPIs are the local government offices with official responsibility for maintaining registration lists. Registration lists are different from lists of existing companies as they do not guarantee that firms are actually operational and do not keep track of firms that have moved to a new location. Even

\footnotetext{
12 According to 1998 figures, the survey designers had available at the time of implementation, these six provinces represented $39 \%$ of all private companies, $28 \%$ of all private manufacturers, and at least $55 \%$ of firms with 100 or more employees (based on information for the four firms that overlapped with the MPDF study). According to 2000 figures gathered later, the six provinces are home to an even higher $47 \%$ of all private companies, $38 \%$ of all private manufacturers and at least $53 \%$ of firms with 100 or more employees.
} 
though most lists provided specific addresses and phone numbers, a significant amount of time was lost at the start of survey implementation trying to locate firms. ${ }^{13}$ In Ha Tay province, in particular, DPI lists were supplemented with company lists provided by the local Department of Labor, Invalids and Social Affairs (DOLISA) in order to increase the number of smaller sole proprietorship enterprises captured in the survey. ${ }^{14}$

17. In 2001, the Vietnamese press frequently reported cases of illegitimate company registrations. Surveyors did encounter a significant number of cases where no company existed at the address of a registered company and no one at the address or in the neighborhood appeared to have ever heard of the company or its owner. Vietnam's press has been quick to label these firms "ghost firms", engaged in some sort of illegal activity, such as trying to access VAT receipts for the use of other businesses. An equally possible explanation is that these firms have registered before starting up operations or have moved their operations elsewhere. ${ }^{15}$ Further research on this issue, its costs, and appropriate policy responses would clearly be useful.

\section{THE CURRENT PICTURE: VIETNAM'S PRIVATE COMPANIES IN 2000}

\section{The Firms}

18. By any measure, Vietnam's domestic formal private sector is, at present, small. Domestic private companies contribute the smallest share of GDP of any enterprise type and employ less than 60 percent as many workers as even the Vietnamese state bureaucracy. The domestic formal private sector is also largely concentrated in the southern third of the country, in cities, and in low sunk cost industries like trade.

\section{Small in Size}

19. Domestic private companies produce 7.6 percent of mational GDP, compared to about a third contributed by state enterprises. In manufacturing, the gap is even larger: the domestic formal private sector's share is nine percent and the state's share is half. In both cases, however, it may be that the private sector's role is somewhat larger than credited by official statistics, as measurement of the sector's output is complicated by private companies' propensity to under-report their activities to avoid high corporate taxes and other, less formal fees. ${ }^{16}$

\footnotetext{
${ }^{13}$ According to CIEM, DPI registration lists were comprehensively checked and updated in 1997 in preparation for a national firm survey. This still means that formal and informal bankruptcies, as well as firm relocations, over the past four years are not accounted for by the lists used for this survey. Other firms also may have registered, but not yet begun operations. Firms are ordinarily removed from DPI lists only after companies do not return required paperwork for two consecutive years.

${ }^{14}$ DOLISA lists are lists of existing private firms that the DOLISA is responsible for supervising with regard to their labor practices. DOLISSA Ha Tay said all the firms on its lists were in operation. Given the limited time frame of the survey, this list proved a more efficient means for selecting and finding relatively small and footloose sole proprietorships - which were the main form of enterprise that most often could not be found from the DPI list.

${ }^{15}$ Registering before starting operations is standard in many countries. If doing so is becoming more common in Vietnam, this might represent a significant change from the first stage of formalization of the private sector in the 1990s when registering private companies were usually pre-existing informal sector firms adjusting to the new legal framework.

${ }^{16}$ The "tall poppy syndrome", which states that private companies in Vietnam are reluctant to grow relatively large for fear of attracting too much negative attention from authorities and regulators, is relevant to this point.
} 


\section{Box 4.1 A Worker's Perspective: Comparing Options}

Ms. Nguyen Thi Ut is 21 years old, the daughter of two rice farmers on the outskirts of Ho Chi Minh City, and currently produces leather shoes for a private shoe company in the city's sixth district. Ms. Ut studied in her hometown until eighth grade before quitting to work in the fields. When she turned 18, family connections helped her get her current job with the shoe manufacturer.

"All the young people from my neighborhood have left to find work like mine," says Ms. Ut. "I have 14 siblings, and only my parents still work the fields. Rice farming is so terribly hard. The money is small and also unstable. And your nails are always black from sticking your hand into the mud. If you have a regular manufacturing job, you can calculate ahead of time the amount of money you have to spend each month, you work in a clean environment, you get to wear nice clothes, and sometimes you go on organized trips to other places."

Planting and transplanting rice in Ms. Ut's hometown pays approximately VND 20,000 a day, equal to a typical income for a manufacturing worker in the city. But such income is not guaranteed day-to-day, with monthly income often totalling only VND 150,000 to VND 300,000. Ms. Ut currently earns an average of VND 800,000 a month. Ms. Ut commutes from her parents home to work, allowing her to save money on housing. When she comes home, she frequently brings work home with her. During busy times, Ms. Ut's parents and siblings spend their evenings sewing shoes together at home with needle and thread, earning VND 1,000 for a pair of shoes that can be finished by one person in about an hour. These months, the family is usually able to earn an extra VND 500,000-600,000. Recently, after three years on the job, and with a partial loan from her grateful parents, Ms. Ut was able to buy a motorcycle for VND three million.

VND $15,000=U S D 1$

20. Eighty percent of Vietnam's workforce is still employed informally in agriculture, self-employment, or unregistered household enterprises. At the end of 2000, the number of people employed by Vietnam's private firms stood at just 800,939-2.1 percent of the national work force. This ranked private companies behind the state administration, state firms, and registered household firms as employment providers. The average private company employs 25 workers, less than a tenth the average state enterprise. 17 Private manufacturers employ a more substantial 69 workers per firm. The largest private firm in the survey employed 3,300 workers.

\footnotetext{
17 A rough estimate of average employment in the SOE sector can be obtained by dividing the total number of employees by the number of enterprises. The state enterprise sector currently employs about 2 million people and there are 5.500 state enterprises (including 730 in public services), giving an average number of employees by enterprise of 365 .
} 
Table 4.1 2000 GDP and Employment by Enterprise Type (\%)

\begin{tabular}{lrr}
\hline & GDP & Employment \\
\hline Public Sector & 40.6 & 8.8 \\
- State Owned Enterprises (SOEs) & 31.6 & 5.2 \\
- State Administration & 9 & 3.6 \\
Collectives & 8.5 & 0.6 \\
Domestic Private Sector & 40.2 & 90.0 \\
- Households \& Farmers & 32.6 & 87.9 \\
$\quad$ * Non-Agricultural HH & & 8.4 \\
- Private Companies & $\mathbf{7 . 6}$ & $\mathbf{2 . 1}$ \\
Foreign-Invested Companies & 10.7 & 0.6 \\
Total & $\mathbf{1 0 0 . 0}$ & $\mathbf{1 0 0 . 0}$ \\
\hline
\end{tabular}

Source: GSO, 2001

21. Average firm size varies based on enterprise form. The smallest form sole proprietorship employs on average just over 10 employees per firm. Limited liability companies average 43 employees and shareholding companies are the biggest with an average of 170 workers. Firms in manufacturing are relatively larger, with average employment per shareholding company reaching 269 workers. Numbers on partnerships are not available. ${ }^{18}$

Table 4.2 Average Firm Size by Enterprise Form

\begin{tabular}{lrrr}
\hline & \%of Total Firms & $\begin{array}{r}\text { Ave. Employees, } \\
\text { Private Firms }\end{array}$ & $\begin{array}{r}\text { Ave. Employees, } \\
\text { Private Manufacturers }\end{array}$ \\
\hline Sole Proprietorship & 61 & 10 & 23 \\
Limited Liability & 37 & 43 & 132 \\
Shareholding & 2 & 170 & 269 \\
\hline
\end{tabular}

Source: GSO, 2001

22. It is clearer with employment than it is with GDP that official statistics fail to capture the full private sector picture. Surveyed manufacturing firms had a mean level of employment of 144 full-time workers per firm-26 percent higher than the GSO average of 114 for the same six provinces. ${ }^{19}$ Applying this mark-up to the entire country, domestic formal private sector employment rises to over a million workers and 2.6 percent of total employment. The survey results indicate that the private sector also creates temporary and seasonal jobs that total an additional 20 percent on top of this estimate, allowing for a rough estimate of three percent for the actual private sector share of total employment.

23. Employment in the formal private sector is underestimated because private companies: i) under-report employment to officials to avoid various fees including worker and health insurance; ii) rely on seasonal or temporary workers, who often are officially categorized under agricultural employment; and iii) outsource work to households because of fluctuations in demand and in order to avoid official labor fees. One of the means by which employers appear to be able to avoid reporting some workers

\footnotetext{
${ }^{18}$ Only five partnerships were set up in the first two years of the Enterprise Law. The survey made a specific effort to include Partnerships, but still only succeeded in capturing one.

${ }^{19}$ Given that interviews were conducted by people attached to the Ministry of Labor, there is reason to believe that employment numbers from the survey are still underestimated.
} 
is to sign them to short-term contracts that do not require the same extra payments as with long-term contracts of a year or more. There is reason to believe that it would be hard for local GSO offices to know the exact work force of a private firm if the firm has succeeded in reducing the number arrived at by local labor authorities.

\section{Box 4.2 Nang Dong Co.: Firm's Dynamism Sews Seeds for Other Firms' Growth}

Nang Dong Company began operations in the 1980s as an informal handicrafts production enterprise, supplying state firms with goods they could export to markets in Eastern Europe. By 1993, the enterprise had grown to employ 200 workers and owner Pham Lac Quan decided to formally register the firm as a sole proprietorship. Mr. Quan was confident the government would soon allow private companies to export directly, thereby cutting out the state middleman and allowing his enterprise to expand further. To further prepare for this change, Mr. Quan reduced his day-to-day role in management and enrolled in the foreign trade university.

When private companies were given the right to export directly in 1998, Nang Dong Company was ready, and soon found itself being approached by other small private enterprises who did not know how to access foreign markets. Mr. Quan realized his expertise would be more optimally utilized if his company transitioned from manufacturing company to trade services companyproviding precisely the services for which his firm had before, at least nominally, had to rely on the state sector. Mr. Quan reduced Nang Dong Company's labor force to 40 workers, including mostly engineers, office workers, and designers who could create models for other companies to produce. Despite this direct reduction in Nang Dong's labor force, the overall employment impact of Mr. Quan's decision proved dramatically positive.

Local suppliers for Nang Dong Company include both formal and informal private firms, not only in its native Ha Tay province, but also nearby Thanh Hoa, Nghe An, and Thai Binh. Today, Nang Dong places orders with 10 different private companies and 20 informal production enterprises. Many of these firms further outsource their orders to rural households with long-time family traditions in particular handicrafts, such as bamboo work - a particularly popular product traded by Nang Dong. Added all together, Mr.Quan insists he is estimating conservatively when he says Nang Dong's market connections result in significant work and income for some 1,700 people in the area. If his business plan is effective, says Mr. Quan assures, this number will nearly triple in the coming five years.

\section{Limited in Scope}

24. Vietnam's private sector is limited geographically. Two-thirds of Vietnam's private companies, and three-quarters of domestic private manufacturers, operate in the South. The formal private sector is also heavily concentrated in urban centers. Ho Chi Minh City alone accounts for almost a quarter of all domestic private firms and all private sector employment in the country. Ho Chi Minh City and Hanoi together make up 40 percent of all Vietnamese private companies. The Mekong Delta region is noteworthy as the one rural area that is home to a large number of formal private firms. 
Table 4.3 Private Companies by Region, 2000

\begin{tabular}{lrr}
\hline Provinces & Firms & Share \\
\hline Red River Delta & 5,732 & $18.1 \%$ \\
- Hanoi & 3,666 & $11.6 \%$ \\
North East & 1,114 & $3.5 \%$ \\
North West & 146 & $0.5 \%$ \\
The North & $\mathbf{6 , 9 9 2}$ & $\mathbf{2 2 . 1 \%}$ \\
North Central Coast & 1,336 & $4.2 \%$ \\
South Central Coast & 2,383 & $7.5 \%$ \\
The Center & $\mathbf{3 , 7 1 9}$ & $\mathbf{1 1 . 8 \%}$ \\
Central Highlands & 1,248 & $4.0 \%$ \\
Northeast South & 12,296 & $38.9 \%$ \\
$\quad$ - Ho Chi Minh City & 9,089 & $28.8 \%$ \\
Mekong River Delta & 7,338 & $23.2 \%$ \\
The South & $\mathbf{2 0 , 8 8 2}$ & $\mathbf{6 6 . 1 \%}$ \\
Total & $\mathbf{3 1 , 5 9 3}$ & $\mathbf{1 0 0 . 0 \%}$ \\
\hline
\end{tabular}

Source: GSO, 2001

25. The survey showed that private companies in the South are more successful than their counterparts in the North. Southern firms claimed mean revenues of nearly three quarters more than firms in the North—a finding consistent with the 1999 MPDF study. ${ }^{20}$ Revenues from exports showed an even more dramatic regional difference, with firms in the South reporting a mean four times higher than that for firms in the North. This difference occurs despite the fact that northern companies tend to actually be larger with regard to workers per firm. It is important to note, however, that there is significant variation between provinces within regions. $^{21}$

Table 4.4 Firm Revenues by Region, 2000 (VND Million)

\begin{tabular}{lrrr}
\hline Region & Mean & Number of Firms & Standard Deviation \\
\hline North & 7,626 & 122 & 12,408 \\
South & 13,079 & 162 & 32,301 \\
Vietnam & $\mathbf{1 0 , 7 3 6}$ & $\mathbf{2 8 4}$ & $\mathbf{2 5 , 8 2 1}$ \\
\hline
\end{tabular}

Source: World Bank Survey, 2001

26. Private firms have also concentrated on a limited number of economic industries. Fifty-seven percent of all domestic private companies are trade and retail services companies. Manufacturing firms account for a fifth of all private companies, but are responsible for 57 percent of formal private sector employment.

\footnotetext{
${ }^{20}$ Webster and Taussig (1999). Vietnam's Undersized Engine, p. 28.

${ }^{21}$ Furthermore, the makeup of official regions used by the GSO has changed in recent years. The authors have made efforts to maintain consistency among regional categories used in this report. The GSO has explained that some movement of provinces from one region to another has been done specifically based on those provinces economic performance-for example, when one province exhibited high growth over a few years, it was moved into a neighboring higher growth region, as officials decided it now had more in common with the higher growth region. This, of course, makes comparing regional performance over a given number of years quite problematic.
} 
Table 4.5 Private Companies by Sector, 2000

\begin{tabular}{lrr}
\hline Sector & Firms & Share \\
\hline Trade and Services & 18,000 & $57.1 \%$ \\
Manufacturing & 6,617 & $21.0 \%$ \\
Construction & 2,400 & $7.6 \%$ \\
Transport & 800 & $2.5 \%$ \\
Mining & 136 & $0.4 \%$ \\
Other & 3,566 & $11.3 \%$ \\
Total & $\mathbf{3 1 , 5 1 9}$ & $\mathbf{1 0 0 \%}$ \\
\hline
\end{tabular}

Source: GSO, 2001

27. Within the manufacturing sector, firms are further highly concentrated in the food and beverage processing subsector-which accounts for 45 percent of all private manufacturers. Considering that four-fifths of the country still lives in the countryside and is closely tied to agriculture, the food and beverage processing industry holds special significance with regard to its potential to stimulate economic activity in the countryside. These firms have the potential to pass on important information on markets and technologies to those in the countryside from whom they source their inputs. Food processing firms tend to be quite small with labor forces of 10-15 workers, though in 2000 there were 36 firms in the subsector with 500 or more norkers. Garments and leather products producers are also important manufacturing subsectors as a result of their high per firm employment of 220 and 624 workers, respectively.

Table 4.6 Private Companies by Manufacturing Subsector, 2000

\begin{tabular}{lr}
\hline Subsector & Firms \\
\hline Food and Beverages & 2,952 \\
Textiles & 172 \\
Garments & 317 \\
Leather Products & 109 \\
Wood Products & 491 \\
Paper Products & 210 \\
Chemical Products & 188 \\
Plastic Products & 256 \\
Non-metallic Products & 696 \\
Metallic Products other than Machinery & 290 \\
Other & 936 \\
\hline
\end{tabular}

Source: GSO, 2001

28. About one third of the manufacturing companies in the survey sell their products directly in foreign markets and generate an average $70 \%$ of their revenues from foreign customers. Exports are mainly concentrated on Asian and European markets. As seen in earlier research, companies with 100 or more workers were particularly likely to be heavily oriented towards exports. Fifty-seven percent of such larger manufacturers named a foreign customer as their most important customer. ${ }^{22}$ Compared with firms in

\footnotetext{
22 This number is actually lower than the number found in research by MPDF in 1999. The difference, however, is most likely the result of the replacement of the highly export-oriented Dong Nai province with rural Long An province in the South-rather than representing a slump in export orientation. In fact, macro statistics indicate that the private sector's role in export has risen in the last couple years.
} 
the MPDF survey in 1999, exporters appear to have increased their direct dealings with customers in high income West European markets.

Table 4.7 Revenues in Exporting Manufacturing Enterprises (\%)

\begin{tabular}{lr}
\hline Market & Share in Revenues \\
\hline Province & 16.5 \\
Other provinces & 13.5 \\
Asia & 29.6 \\
Europe & 35.5 \\
Northern America & 3.1 \\
Other & 1.8 \\
Total & $\mathbf{1 0 0 . 0}$ \\
\hline
\end{tabular}

Source: World Bank Survey, 2001

\section{The Managers}

29. The profile of the manager found in this survey is very much in line with earlier studies of private companies. The manager of a private enterprise is on average 45 years old. The youngest entrepreneur in the sample was 21 years old, while the oldest was 71 . Three quarters are men and one-quarter women. The proportion of women entrepreneurs is higher in rural than in urban areas. Owners of enterprises are well educated: more than two-thirds of owners graduated college. ${ }^{23}$ The average level of education is also relatively higher in the North and in urban areas. It is not clear, however, that this education advantage translates into any advantage in bus iness. ${ }^{24}$

Table 4.8 Gender of Firm Managers (\%)

\begin{tabular}{lrrr}
\hline & Urban & Rural & Total \\
\hline Male & 81.0 & 68.1 & 76.4 \\
Female & 19.0 & 31.9 & 23.6 \\
Total & $\mathbf{1 0 0 . 0}$ & $\mathbf{1 0 0 . 0}$ & $\mathbf{1 0 0 . 0}$ \\
\hline
\end{tabular}

Source: World Bank Survey, 2001

Table 4.9 Education of Managers by Firm Location (\%)

\begin{tabular}{lrrrrr}
\hline & North South & Urban & Rural & Total \\
\hline Graduated College & 77.5 & 58.1 & 78.7 & 46.5 & 67.2 \\
Graduated High School & 21.4 & 26.5 & 19.0 & 33.3 & 24.1 \\
Graduated Elementary School & 1.1 & 12.1 & 1.9 & 16.0 & 7.0 \\
Did Not Yet Graduated Elementary & 0.0 & 3.3 & 0.4 & 4.2 & 1.7 \\
School & & & & & \\
Total & $\mathbf{1 0 0 . 0}$ & $\mathbf{1 0 0 . 0}$ & $\mathbf{1 0 0 . 0}$ & $\mathbf{1 0 0 . 0}$ & $\mathbf{1 0 0 . 0}$ \\
\hline
\end{tabular}

Source: World Bank Survey, 2001

30. The majority of owners $(83 \%)$ did not own a business before. On average, 30 percent of the owners worked in the informal sector before, a higher 39 percent in rural areas and 23 percent in urban areas. About 40 percent used to work in a state enterprise, but less than ten percent had previously been in government. The proportion of owners that worked for a state enterprise before is particularly high in the North (52\%).

\footnotetext{
${ }^{23}$ This represents an increase from the finding of one half in the MPDF study. This may be accounted for by higher education levels among service firm managers.

${ }^{24}$ As in MPDF's 1999 study, educated managers actually did somewhat worse than the rest of the sample.
} 
Table 4.10 Previous Profession of Firm Managers (\%)

\begin{tabular}{lllll}
\hline & Manufacturing & Other Indus try & Services & Total \\
\hline Agriculture (Informal) & 1.9 & 0.0 & 0.9 & 1.2 \\
Trade (Informal) & 9.7 & 12.1 & 25.8 & 18.5 \\
Manufacturing (Informal) & 14.2 & 3.0 & 6.1 & 9.0 \\
Collective & 4.5 & 0.0 & 0.5 & 2.0 \\
Private Company & 13.5 & 18.2 & 16.0 & 15.2 \\
State Enterprise & 41.9 & 51.5 & 38.0 & 40.6 \\
Organization under VCP, & 11.0 & 12.1 & 7.0 & 9.0 \\
Government, Army & & & & \\
Other & 3.2 & 3.0 & 5.6 & 4.4 \\
Total & $\mathbf{1 0 0 . 0}$ & $\mathbf{1 0 0 . 0}$ & $\mathbf{1 0 0 . 0}$ & $\mathbf{1 0 0 . 0}$ \\
\hline Source: & & &
\end{tabular}

Source: World Bank Survey, 2001

\section{Box 4.3 Nong Thon Garments Ltd.: Management's View of Rural-Urban Transition}

Two thirds of Nong Thon Garment Company Ltd.'s workers are from the countryside. This, says General Director Mr. Pham Quan Tri, comes with its drawbacks. "Workers still act very much like countryside people. Sometimes people quit or are fired because of fighting with each other. If the owner is short with them, they get angry and do not listen and improve their approach to work. They have trouble distinguishing between the way people interact at home and the way they interact out in society and in business." Annual worker turnover at Nong Thon is about 300 a year, or more than 20 percent of the current work force. Reasons for leaving work commonly involve a violation of company rules, pregnancy or marriage, changing profession, getting old, or switching jobs for a higher salary.

Mr. Tri says the dynamics between manager and worker in the private sector are often misunderstood, leading to a negative reputation for the private sector. "The Vietnamese media still commonly uses the derogatory work for traders to refer to private firms", says Mr. Tri. "Maybe this is just a habit of language, but it reflects a general way of thinking that pervades society. People think that owners are always firing their employees, but don't understand that we also always fear that our employees will suddenly quit. We should be more valued for our efforts to be more efficient, as it contributes to the wealth of the nation."

Despite such challenges, Nong Thon Garments is doing well. In January 2000, the firm expanded from two factories to four, and with that change double its work force from 700 to 1,440 employees. Mr. Tri began putting ads in the newspaper and contacting job introduction services and training schools only two months before making the two new factories operational, but still found himself awash in applicants. Knowing that many of his prospective employees would have just recently left their homes in the countryside, Mr. Tri did not ask for resident permission papers or letters of recommendation. After being hired, says Mr. Tri, workers usually undergo training for anywhere between six to 12 months.

\section{The Workers}

31. More than half of the workers with private Vietnamese companies are women. This is because women make up two-thirds of the workers at private manufacturing firms, the largest type of private company. Garments and leather goods producers, in particular, overwhelmingly hire female workers.

32. For many workers in the private sector, employment is not very secure. In the manufacturing sector only 50 percent of workers have long-term stable contracts. The 
other half is more temporary workers, at least with regard to their actual contractsthough many may actually be on the job as much as those with long-term contracts. The least stable of all industrial sectors is construction, where most workers are temporary workers. Construction workers commonly work as farmers at harvest times and then come into the city to supplement their incomes. Service jobs in the formal private sector are generally more secure. About two-thirds of service workers have long-term contracts. The issue of avoiding labor fees through use of short-term contracts is likely to be less of an issue for service companies, given their smaller size. ${ }^{25}$ Service firms also frequently hire more educated workers and may feel more of a need to sign longer-term contracts to guard against high turnover.

\section{Box 4.4 The Case of Xuan Thu Company: Seasons Change, Workers Change}

Pham Dung is the 29-year old owner of a private construction company with seven official employees: a secretary, an accountant, two technical engineers, a main construction expert and two sales people. At times, however, Mr. Dung's company, Xuan Thu Company, employs as many as 140 full-time workers. Unless it has no ongoing projects, Xuan Thu Company actually rarely dips below 18 employees. But as far as labor authorities and, in all likelihood, statistics officials are concerned, employment with the firm stands at just seven.

According to Mr. Dung, short-term labor contracts are the only possible way to operate effectively in the construction business. When Xuan Thu has a project to build a villa, it needs 20 workers; when repairing a neighborhood water system it may be just seven workers; building a runway at the airport, in turn, requires 130 . No firm manager wants to pay workers when there are no projects, he says. And workers don't want to be tied to relatively low paying contracts during downtime when they could be working for more pay on a different project for a different firm. According to Mr. Dung, "Total income is much more important to them than stability. Workers want to maximize their time as they are overwhelmingly from the countryside, often coming in groups from far off provinces in other regions of the country when there are no crops to tend to at home. Even so, they often go months without work - on average about three months of the year."

33. There may be a number of reasons why workers are not given long-term contracts. One would be the highly seasonal nature of many private sector activities. Private enterprises are relatively small in size and cannot afford idle labor. Consequently they are able to wait to hire short-term labor until a specific need arises, for example at the time of a large order. In the context of high rural underemployment and significant urban unemployment, employers do not find it difficult to find temporary workers when they need them. Social security regulations and official labor fees are also given as a reason by many employers for why they do not recruit workers on a more permanent basis. Social security taxation is 20 percent, which many enterprises consider too high. Employers also complain that contracts are only binding on them and not the employee and claim to have significant turnover among their staff-particularly among lowerskilled manufacturing workers.

\footnotetext{
${ }^{25}$ Labor fees become a significant cost only after a firm grows to beyond 10 employees.
} 
Table 4.11 Employment by Sector and Gender, 2000

\begin{tabular}{lcrrr}
\hline Industries & & Total Workers & Female Workers & Long Term contract \\
\hline Manufacturing & Mean & $\mathbf{1 4 4}$ & $\mathbf{9 3}$ & $\mathbf{7 4}$ \\
& Minimum & 2 & 0 & 0 \\
\multirow{5}{*}{ Other industry } & Maximum & 3,300 & 2,100 & 1,594 \\
& Mean & $\mathbf{5 9}$ & $\mathbf{7}$ & $\mathbf{1 8}$ \\
& Minimum & 3 & 0 & 0 \\
Services & Maximum & 434 & 64 & 85 \\
& Mean & $\mathbf{3 3}$ & $\mathbf{1 1}$ & $\mathbf{2 6}$ \\
\multirow{5}{*}{ Total } & Minimum & 2 & 0 & 0 \\
& Maximum & 1,420 & 682 & 1,397 \\
& Mean & $\mathbf{7 8}$ & $\mathbf{4 2}$ & $\mathbf{4 4}$ \\
& Minimum & 2 & 0 & 0 \\
& Maximum & 3,300 & 2100 & 1594 \\
\hline
\end{tabular}

Source: World Bank Survey, 2001

34. Education The private sector attracts the higher end of the workforce, in terms of education. The majority has at least a high school diploma and less than 10 percent of shop floor workers did not graduate elementary school. By contrast, only 17 percent of Vietnam's labor force finished high school and up to 50 percent has not finished elementary education.

35. Workers in the service sector are relatively higher educated than workers in the industrial sector. The majority of manufacturing workers have either a elementary or high school education. The level of education of private sector workers is also higher in urban areas than in rural areas. This may be due to the higher concentration of educated workers in urban areas, but also the result of a higher incidence of service activities. ${ }^{26}$

Table 4.12 Mean Level of Education for Shop Floor Workers, 2000

\begin{tabular}{lcrrr}
\hline \multicolumn{4}{c}{ Industries } & \multicolumn{4}{c}{ Percentage of Workers with... } \\
& $\begin{array}{r}\text { College } \\
\text { Degree }\end{array}$ & $\begin{array}{r}\text { High School } \\
\text { Diploma }\end{array}$ & $\begin{array}{r}\text { Elementary } \\
\text { School }\end{array}$ & $\begin{array}{r}\text { Not Yet Finished } \\
\text { Elementary School }\end{array}$ \\
\hline Manufacturing & 10.7 & 49.0 & 28.9 & 11.6 \\
Other industry & 23.8 & 38.0 & 27.0 & 11.2 \\
Services & 32.0 & 48.3 & 16.1 & 3.5 \\
Total & 23.2 & 47.8 & 21.9 & 7.2 \\
Total Labor & 17.0 & & 33.0 & 50.0 \\
Force & & & & \\
\hline
\end{tabular}

Source: World Bank Survey, 2001

36. Wages. The average monthly wage of shop floor workers is VND 720,000 in the manufacturing sector and about 920,000 in the service sector.

\footnotetext{
${ }^{26}$ The VLSS 97-98 showed how the share of people with higher qualifications is increasingly concentrated in urban areas, leaving rural areas without strong educational or technical expertise.
} 
Table 4.13 Average Monthly Wages, 2000 (1000 VND)

\begin{tabular}{lcrr}
\hline Industries & & Direct Workers & Management \\
\hline Manufacturing & Mean & 721 & 1,324 \\
& Minimum & 228 & 500 \\
\multirow{4}{*}{ Other industry } & Maximum & 1,700 & 4,500 \\
& Mean & 914 & 1,490 \\
& Minimum & 400 & 650 \\
Services & Maximum & 2,000 & 3,000 \\
& Mean & 916 & 1,540 \\
& Minimum & 300 & 518 \\
& Maximum & 2,590 & 5,000 \\
\hline
\end{tabular}

Source: World Bank Survey, 2001

37. The VLSS data show that wages of workers in the formal private sector are about 50 percent higher than those in the informal sector, but generally lower than wages in state owned enterprises and foreign invested companies.

Table 4.14 Average Annual Compensation, 1997-1998 (1000 VND)

\begin{tabular}{lr}
\hline Sector & Total Annual \\
\hline Government & 5,894 \\
Party/Mass Organization & 5,044 \\
SOE & 9,258 \\
Cooperative & 2,688 \\
Private Company * & 7,970 \\
Household & 5,402 \\
Foreign & 9,376 \\
Other & 3,870 \\
Total & $\mathbf{6 , 4 3 6}$ \\
\hline
\end{tabular}

Source: VLSS 1997-98

* The private company category includes sole proprietorships, not limited liability or shareholding companies

38. Private sector jobs often come with less non-salary benefits than more highly sought after, but rare, state jobs. Surveyed companies reported spending only seven percent of total labor costs on social insurance and just two percent on training. Firms that rely heavily on short-term labor are of course able to cut down on their required payments, but even some firms with very high numbers of long-term contracted workers claimed very low social insurance payments.

\section{Table 4.15 2000 Firm Spending on Workers}

\begin{tabular}{lr}
\hline & Share (\%) \\
\hline Salary in cash & 90.2 \\
Benefits in other form & 0.2 \\
Social Insurance & 7.0 \\
Training & 2.4 \\
Bonus & 0.2 \\
Total & $\mathbf{1 0 0 . 0}$ \\
\hline
\end{tabular}

Source: World Bank Survey, 2001 


\section{Box 4.4 Contracts Not Yet Automatic Feature of Private Sector Employment}

In 1994, Ms. Tran Thi Huong accepted a modestly paid accounting with a branch office of Thang Cong Private Company, one of Vietnam's best known domestically oriented private companies. Feeling fortunate to have gotten the job, Ms. Huong at first did not object to the lack of a contract, particularly since nobody else in the office had ever signed one. Her lack of a contract meant no social or health insurance payments were made for her, but the pay was enough and Ms. Huong held little regard for public health care.

After adjusting to the work, however, Ms. Huong decided to ask for an increase in pay from her starting rate of VND one million (US\$ 67) a month. Six years later, when a raise had still not come through, Ms. Huong decided to give notice of her plans to switch to a new job. In response, Thang Cong offered her a raise to VND 1.5 million (US\$100) a month and the opportunity to sign a contract, but Ms. Huong's patience was at an end and she refused. Unable to convince Ms. Huong to stay, the company decided not to pay her any severance pay-in Vietnam expected to be about 3-6 months pay for six years of service.

When Ms. Huong specifically requested severance pay, the head of Thang Cong's Ho chi Minh City branch responded, "If you don't reveal any internal information, then at some later time we will look into this issue and resolve it". Two months later, only when the company needed Ms. Huong to return to help with some tax accounting matters, Ms. Huong was paid VND three million (US\$200), a lump sum not based on any particular legal or systematic principle under the Labor Law. Dissatisfied with the behavior of Thanh Cong, Ms. Huong finally began to read the Labor Law and sought out a legal consultant, but by then it was too late. With no official contract, Ms. Huong had no legal basis for her complaints.

39. The majority of workers are recruited either within the same district or the same province. Consistent with their reputation for commonly hiring underemployed farm labor, surveyed construction firms reported the highest numbers of workers from outside the province. Workers are mainly recruited through informal channels, like word of mouth through existing employees and family and friends.

Table 4.16 Origin of Company Workers, Shares (\%)

\begin{tabular}{lrrrrr}
\hline Industries & $\begin{array}{r}\text { Same district } \\
\text { or village }\end{array}$ & $\begin{array}{r}\text { Other districts in } \\
\text { same province/city }\end{array}$ & $\begin{array}{r}\text { NeighboringOther provinces } \\
\text { province }\end{array}$ & Total \\
\hline Manufacturing & 44 & 27 & 18 & 11 & 100 \\
Other industry & 27 & 40 & 21 & 12 & 100 \\
Services & 36 & 44 & 9 & 11 & 100 \\
Total & $\mathbf{3 9}$ & $\mathbf{3 7}$ & $\mathbf{1 3}$ & $\mathbf{1 1}$ & $\mathbf{1 0 0}$ \\
\hline
\end{tabular}

Source: World Bank Survey, 2001 


\section{TRENDS}

\section{Is Formalization of Vietnam's Private Sector on the Rise?}

40. The jump in private sector registrations since implementation of the 1999 Enterprise Law has led to a common assumption that Vietnam's formal sector has turned a corner and is now on the rise. A closer look at the data on existing Vietnamese private companies reveals a more ambiguous picture.

- The sector's share of GDP has remained constant

- The number of firms has grown, though more modestly than indicated by registrations

- Employment has grown dramatically, particularly, it seems, in the past year

41. The domestic formal private sector's 7.6 percent share of Vietnam's GDP at the end of 2000 was the same as five years earlier at the end of 1995. The contribution of Vietnam's state enterprises has also remained unchanged, with the only significant development being a fall in the informal private sector's share in favor of growth among foreign-invested companies. As such, there has indeed been an increase in the GDP share of the total formal private sector, i.e. the combination of the foreign and domestic formal private sectors. It is, however, probably too early to see the GDP effects of private sector growth under the Enterprise Law as these firms were mostly new firms registering throughout the year, many of which probably began with investments but not immediate outputs. Registered capital, one of the few available indicators of private sector investment, has indeed been on the rise since $1997 .^{27}$

Table 5.1 GDP by Enterprise Form, 1996 and $2000(\%)$

\begin{tabular}{lrrr}
\hline & Shares & \multicolumn{2}{c}{ Growth } \\
\hline & $\mathbf{1 9 9 6}$ & $\mathbf{2 0 0 0}$ & Average YoY \\
\hline State Sector & 40.8 & 40.6 & 7.3 \\
Non-state Sector & 59.2 & 59.4 & 6.7 \\
$\quad$ - Domestic non-state & 42.7 & 40.2 & 5.1 \\
$\quad$ - Households \& Farmers & 35.0 & 32.6 & 4.9 \\
$\quad$ - Private Companies & 7.6 & 7.6 & 7.1 \\
- Sole Proprietorship & 3.2 & 3.3 & 8.5 \\
$\quad$ - Ltds. and & 4.4 & 4.3 & 6.1 \\
-SChahledoiddeng & 9.2 & 8.5 & 4.1 \\
- Foreign Invested & 7.3 & 10.7 & 17.4 \\
Total & $\mathbf{1 0 0 . 0}$ & $\mathbf{1 0 0 . 0}$ & $\mathbf{7 . 0}$ \\
\hline
\end{tabular}

Source: GSO, 2001

42. Developments in manufacturing have been similar, with even greater growth among foreign firms and, consequently, even greater growth in the collective formal private sector. The slight fall in the domestic formal private sector's share is somewhat deceptive, as it varies depending on the way in which GDP is measured. ${ }^{28}$

\footnotetext{
${ }^{27}$ Steer, L. (2001). The Private Sector in Vietnam. p. 9.

${ }^{28}$ The domestic formal private sector's share of GDP measured in nominal terms actually rose over the given period. A possible explanation for this is the private sector's significantly higher export-orientation (as implied by the 1999
} 
Table 5.2 Manufacturing GDP, 1996 and 2000 (\%)

\begin{tabular}{lrrr}
\hline & Shares & \multicolumn{2}{c}{ Growth } \\
\hline & $\mathbf{1 9 9 6}$ & $\mathbf{2 0 0 0}$ & Average YoY \\
\hline State Sector & 58 & 50 & 8 \\
Non-state & & & 12 \\
$\quad$ - Domestic Non-State & 28 & 29 & $\mathbf{9}$ \\
$\quad$ - Formal Private & $\mathbf{1 0}$ & $\mathbf{9}$ & -2 \\
$\quad$ - Collectives & 1 & 1 & 29 \\
$\quad$ - Foreign Invested & 13 & 21 & $\mathbf{1 1}$ \\
Total & $\mathbf{1 0 0 . 0}$ & $\mathbf{1 0 0 . 0}$ & \\
\hline
\end{tabular}

Source: GSO, 2001

43. The year 2000 clearly saw a major increase in Vietnam's total number of operating private companies. The increase in actual operating firms appears, however, to have been significantly less than the record number of registrations. The exact amount of the increase is not clear due to inconsistent data collection methodology by GSO. If GSO 1999 numbers are to be believed, 2000 saw an increase of 6,182 companies-a one year record. However, alternate figures estimated by GSO officials suggest that 1999 figures were underestimated by as much as 2,000 firms, thereby reducing the one-year increase to about 4,000. ${ }^{29}$ Even at 4,000, though, 2000 witnessed one of the largest annual increases in private companies since their legalization at the start of the 1990s. The increase is particularly impressive in light of the preceding slow down which saw the number of private companies grow by only four percent in 1998 and possibly even fall in 1999.

Table 5.3 Total Registrations and Existing Companies, 1998-2000

\begin{tabular}{llll}
\hline & $\mathbf{1 9 9 8}$ & $\mathbf{2 0 0 0}$ & $\mathbf{1 9 9 8 - 2 0 0 0}$ Growth \\
\hline Total Registrations & 37,050 & 55,120 & $48.8 \%$ \\
Existing Companies & 26,021 & 31,593 & $21.4 \%$
\end{tabular}

Source: GSO and MPI, 2001

44. Using more reliable 1998 numbers for comparison, the difference in the discrepancy between total registrations and existing companies remains striking: from $30 \%$ in 1998 to $43 \%$ in 2000 . This discrepancy becomes more dramatic when one focuses in on company forms. While 8,276 new sole proprietorships regis tered in 1999 and 2000, the overall number of firms only increased by 654 . In manufacturing, the number of sole proprietorships actually fell by two percent. Over the same period, limited liability firms increased their number by 64 percent and sharehold ing companies by 231 percent.

Webster and Taussig study that showed exports to be the main source of revenues for $82 \%$ of private firms with 100 or more employees), given the substantial depreciation of the Vietnamese Dong over the period in question.

${ }^{29} 1999$ figures are considered faulty because they were not double-checked by GSO through use of a national firmlevel survey. In 1998 and in 2000, such surveys were conducted. In both cases, original numbers provided by local statistics offices were increased. The fall in firms shown by GSO is particularly worthy of distrust when seen in this light. Furthermore, GSO experts confirmed that this figure was likely an underestimation of about 2,000 firms. Interestingly, in 1999, the fall in total number of firms is entirely accounted for by the disappearance of some 2,000 sole proprietorships. 
Table 5.4 Registrations and Increase in Private Companies, 1999-2000

\begin{tabular}{lrrrr}
\hline & $\begin{array}{r}\text { Sole } \\
\text { Proprietorships }\end{array}$ & $\begin{array}{r}\text { Limited Liability } \\
\text { Firms }\end{array}$ & $\begin{array}{r}\text { Shareholding } \\
\text { Firms* }\end{array}$ & $\begin{array}{r}\text { Total } \\
\text { Firms }\end{array}$ \\
\hline Registrations & 8,276 & 8.863 & 877 & 18,016 \\
Increase in & 654 & 4,523 & 395 & 5,572 \\
existing & & & & \\
companies & & & & \\
\hline
\end{tabular}

Source: GSO and MPI, 2001 - * The GSO's category of shareholding companies does not appear to include equitized firms [and registration numbers?]

45. Possible reasons for the growing gap between registrations and existing companies include:

- Flawed data collection methods by GSO

- Re-registration by existing companies ${ }^{30}$

- Consolidation of existing companies

- Death or bankruptcy of firms

- Firms registered but not yet operational

- Firms registered but temporarily not operational

- Firms registered and operational but too small and/or mobile to be noticed

- "Ghost" firms set up for non-productive, perhaps illegal, purposes such as receiving VAT receipts or money laundering

46. The fact that it is sole proprietorships that exhibit the largest discrepancy between registrations and accounted-for firms is consistent with a number of the above possibilities including re-registration, death or bankruptcy, and firms registered but not yet operational or temporarily out of operations. Sole proprietorships would be most likely to re-register under a new form if they wanted to access financing so that they could avoid full liability. The new ease of registration under the Enterprise Law would then have offered them the opportunity to do so at minimal cost. ${ }^{31}$ Sole proprietorships' small size also makes them most vulnerable to increased competition or other sudden market swings. Their small size could also make it easier for GSO to simply miss them. Finally, one of the defining benefits of registering as a sole proprietorship is the ability to legally avoid tax payments and potentially other official attention when not in operation. $^{32}$

47. Consolidation of companies is also a possibility, but supporting evidence is scarce. The fairly closed, often family-centered nature of ownership among companies makes consolidation seem somewhat unlikely. There is reason to believe, though, that an

\footnotetext{
${ }^{30}$ MPI keeps figures on the number of firms that have registered in order to increase their registered capital and/or to add or change their areas of economic activity. In the first 23 months after implementation of the Enterprise Law, this number was 8,032. CIEM researchers, however, warned against calculating the number of new start ups by simply subtracting this re-registration number from total new registrations (CIEM, 2002).

${ }^{31}$ The SSE-NIAS survey in 1997 also showed that many firms close down and then re-open and re-register, with the specific aim of gaining access to tax holidays.

${ }^{32}$ It is unclear whether this truly means that local officials treat sole proprietorships any differently than other company forms.
} 
increasingly competitive and changing domestic business environment and the effects of the regional financial crisis-both in leading Southeast Asian nations to reduce spending and investment and leading to a reduction in the cost of imports-might be leading to a higher mortality rate among private firms. It would also make sense that the ease with which one can now register an enterprise has led entrepreneurs to do so earlier than they used to, and sometimes to do so before having secured financing, equipment, or markets. As noted earlier, further research to identify which causes are most important would be of value to policy makers.

48. The most encouraging finding of this report is the strength with which employment is now growing in the domestic formal private sector. From 1995 to 2000, both the absolute number of people working for private companies and the formal private sector's share of total employment have more than doubled. Over the same period, formal private sector employment grew at an impressive annual rate of 19 percent. If 1999 figures are to be believed, 2000 saw the private sector create almost 250,000 new jobs-an increase of nearly 45 percent. ${ }^{33}$ It can be asserted with more certainty that the years 1999 and 2000 saw very impressive average annual labor growth of nearly 30 percent. Over the 1995-2000 period, state sector employment meanwhile grew at comparatively modest rate of 5.4 percent a year. As noted earlier, it is furthermore likely that employment in private companies is significantly under-reported.

Table 5.5 Distribution of Labor Force, 1996 and 2000

\begin{tabular}{lrr}
\hline & 1996 & 2000 \\
\hline Total Labor Force & $35,866,175$ & $38,643,100$ \\
& & \\
Public Sector & $8.9 \%$ & $8.8 \%$ \\
- State Enterprises & $5.2 \%$ & $5.2 \%$ \\
- State Administration & $3.6 \%$ & $3.6 \%$ \\
Non-State & $91.1 \%$ & $91.2 \%$ \\
- Domestic Private & $90.2 \%$ & $90.0 \%$ \\
$\quad$ - Households and Farmers & $89.1 \%$ & $87.9 \%$ \\
$\quad$ - Non-agricultural & $8.1 \%$ & $8.1 \%$ \\
$\quad$ Household enterprises & & \\
$\quad$ - Private Companies & $\mathbf{1 . 1 \%}$ & $\mathbf{2 . 1 \%}$ \\
FDI Enterprises & $0.6 \%$ & $0.6 \%$ \\
Collectives & $0.3 \%$ & $0.6 \%$ \\
\hline
\end{tabular}

Source : GSO, 2001

\section{Is the Formal Private Sector Diversifying Geographically?}

49. Private companies thrive not only in a good policy environment, but also when they are in the company of other dynamic private companies that can help provide needed services and to drive competition. As such, it is not surprising that private companies are often found in clusters. Given the large income differences seen in Vietnam across regions and between cities and the countryside, as well as the troubling problem of

\footnotetext{
${ }^{33}$ Statistics gathered by CIEM through local DPIs shows creation of about 450,000 new jobs in 2000 and 2001. These statistics, however, assume that all registered firms are indeed new firms, rather than re-registering firms. These figures also do not include employment creation by existing private companies. Significantly, half of all new jobs created by new firms were located in Ho Chi Minh City.
} 
increasing underemployment in rural areas, there is, however, rationale behind the desire to see the private sector take greater root outside its traditional strongholds. While causation has not been established, there is a strong association between high levels of private sector development and low levels of poverty in Vietnam.

50. Seen across Vietnam's main three geographic divisions-North, Center, Souththe domestic formal private sector is indeed diversifying. For the past five years, the shares of the North and Center have steadily risen. In the past two years, this trend has accelerated, with the percentage of northern firms increasing from 17 percent to 22 percent. Over the same period the Center's share also increased three percentage points, leaving the South's share to fall from 74 percent to 66 percent. Given the South's enormous lead, however, one must be cautious in assuming that the beginning of a convergence of the three regions' shares necessarily means that the degrees of business friendliness among different local policy environments are also converging. The South may, instead, have hit a point of diminishing growth due to the sheer size of its existing set of companies.

Table 5.6 Private Companies by Region, 1998 and 2000

\begin{tabular}{lrrrrr}
\hline & & \multicolumn{4}{c}{$\begin{array}{l}\text { Percentage of } \\
\text { Registered Firms } \\
\text { Not Accounted For }\end{array}$} \\
\hline Provinces & $\mathbf{1 9 9 8}$ & $\mathbf{2 0 0 0}$ & $\begin{array}{r}\mathbf{1 9 9 8 - 2 0 0 0} \\
\text { Growth }\end{array}$ & $\mathbf{1 9 9 8}$ & $\mathbf{2 0 0 0}$ \\
\hline Red River Delta & 3602 & 5732 & $59.1 \%$ & $33.1 \%$ & $40.5 \%$ \\
North East & 752 & 1114 & $48.1 \%$ & $30.1 \%$ & $41.0 \%$ \\
North West & 74 & 146 & $97.3 \%$ & $27.5 \%$ & $22.3 \%$ \\
The North & $\mathbf{4 4 2 8}$ & $\mathbf{6 9 9 2}$ & $\mathbf{5 7 . 9 \%}$ & $\mathbf{3 2 . 6 \%}$ & $\mathbf{4 0 . 3 \%}$ \\
North Central Coast & $\mathbf{7 2 4}$ & 1336 & $84.5 \%$ & $35.1 \%$ & $33.9 \%$ \\
South Central Coast & 1568 & 2383 & $52.0 \%$ & $44.0 \%$ & $40.8 \%$ \\
The Center & $\mathbf{2 2 9 2}$ & $\mathbf{3 7 1 9}$ & $\mathbf{6 2 . 3 \%}$ & $\mathbf{5 2 . 2 \%}$ & $\mathbf{3 2 . 6 \%}$ \\
Central Highlands & 584 & 1248 & $113.7 \%$ & $44.0 \%$ & $37.1 \%$ \\
Northeast South & 11062 & 12296 & $11.2 \%$ & $16.5 \%$ & $42.0 \%$ \\
Mekong River Delta & 7655 & 7338 & $-4.1 \%$ & $36.8 \%$ & $48.6 \%$ \\
The South & $\mathbf{1 9 3 0 1}$ & $\mathbf{2 0 8 8 2}$ & $\mathbf{8 . 2 \%}$ & $\mathbf{2 6 . 2 \%}$ & $\mathbf{4 4 . 7 \%}$ \\
Total & $\mathbf{2 6 0 2 1}$ & $\mathbf{3 1 5 9 3}$ & $\mathbf{2 1 . 4 \%}$ & $\mathbf{2 9 . 8 \%}$ & $\mathbf{4 2 . 7 \%}$ \\
\hline
\end{tabular}

Source: GSO, 2001

51. It is interesting to note that, while new registrations were indeed higher in the North and Center over the two-year period, it was in fact a rapidly increasing divergence between registrations and existing companies in the South that was the main reason that the other two regions were able to gain significant ground. Again, it was mostly divergence between the registration and existence of sole proprietorships, in particularly, that accounts for the overall difference. Possible reasons for this divergence have already been discussed.

52. Much of the poor performance of the private sector in the South occurred in a the northeastern most provinces of the Mekong Delta—six provinces lying between Ho Chi 
Minh City to the north and Can Tho to the south. ${ }^{34}$ A total of 1,011 new companies registered in these six provinces in 1999 and 2000, but the same period of time saw the number of existing companies fall from 4,117 to 3,590 .

53. Very specifically, the problem lay with small food and beverage processing firms. The number of sole proprietorships active in food and beverage processing in these six provinces fell from 1,213 firms in 1998 to 910 in 2000-single-handedly putting the subsector at negative growth for the whole country. This would quite clearly not appear to be an instance of consolidation since the number of workers for these firms fell by a comparable 27 percent. Weather may have been a factor, as this region has been hit very hard by flooding in the past two years - though frequent flooding in previous years does not seem to have had much effect on entrepreneurship.

54. The most plausible story comes from evidence in the media and in individual firm interviews that many domestic food and beverage processing businesses focused on local markets have failed in the past two years because of competition from both foreign invested firms and from imports. Official statistics also show that output in the canned fruit industry has fallen across all industry types. Local producers have not been able to match the technology or marketing of foreign products and have developed a significantly inferior reputation for quality among consumers. The devaluation of regional currencies in the wake of the Southeast Asian financial crisis may also well have led to a rapid increase in certain food and beverage imports. Further research into the economic consequences in this region of relatively high private sector activity would be useful.

55. While there has been convergence, broadly speaking, between regions, the growth appears to still be very much focused on urban commercial centers. Again, this is normal considering private companies' tendency to grow in groups, but the case of southern China has led to a hope that the countryside can also benefit from private sector development. The recent difficulties of the private sector in the Mekong Delta-home to the second highest number of private firms in Vietnam-indicates that current trends do not have Vietnam replicating the rural successes of China. Ho Chi Minh City increased its dominant position, increasing its share from 24 percent in 1998 to 29 percent in $2000{ }^{35}$ Hanoi also increased its share from eight percent of total private companies to 12 percent. As a result, the two main commercial centers increased their collective share from 32 percent to 41 percent. Growth has also been centered on secondary cities like Hai Phong and Danang and in industrialized provinces near commercial centers such as Binh Duong and Dong Nai-two provinces bordering Ho Chi Minh City and well-known for their pro-business local governments.

\section{Is the Formal Private Sector Increasing Its Activities in Export-oriented and Labor- intensive Industries?}

56. Vietnam's need to create jobs for its rapidly increasing labor force is potentially also the country's greatest strength. Relatively well-educated, low-cost labor is broadly

\footnotetext{
${ }^{34}$ Long An, Dong Thap, Tien Giang, Vinh Long, Ben Tre, and Tra Vinh.

${ }^{35}$ Ho Chi Minh City's dominant role in ongoing growth is particularly clear when one looks at employment figures. As noted in an earlier footnote, preliminary CIEM data on the first two years of new registrations under the Enterprise Law show half the new jobs with new firms to be located within Ho Chi Minh City.
} 
accepted as the Vietnamese economy's leading comparative advantage and will become increasingly important as Vietnam's government follows through on its commitments to freer trade at home and its companies look more to global markets.

\section{Box 5.1 Xuat Khau Ltd.: Export Focus Leads to More Jobs, Better Pay}

Mr. Dao Duy Binh's family has been in the ceramics business for as long as he can remember. Located in rapidly industrializing Binh Duong province, his company, Xuat Khau, Ltd., is one of Vietnam's most successful and well-known ceramics producers-exporting about 80 percent of its goods, mostly to markets in Europe.

Before the start of Vietnam's doi moi economic reforms in the mid-1980s, Mr. Binh's business was an informal enterprise of 60 employees producing goods entirely for the domestic market. The need for employment was evaluated on a day-to-day basis, with employees getting paid only for those days they worked. No orders, no work. Average monthly income per worker was usually not enough to cover living costs for even one individual.

The onset of the doi moi era allowed Mr. Binh to re-establish relations with contacts in European markets. In 1986, Mr. Binh signed his first export contract through the auspices of a state enterprise with the power to export, and immediately hired on an additional 140 workersbringing his total work force to 200. Early in the 1990s, the business was registered as Xuat Khau Ltd. and was able to lower operating costs by exporting directly. In order to keep up with increasing demand, factory space was expanded and the labor force again increased to nearly 600 workers. Average salaries rose to a relatively high VND 500,000 (US\$33) a month, with per person incomes heavily dependent on how much they actually produced. The salary structure became increasingly diversified, as skilled workers who produced a lot earning more, those who produced less earning less. Today, Xuat Khau employs on average 1,200 workers and salaries vary from VND 300,000 (US\$20) all the way up to VND 4,000,000 (US\$267) for highly skilled technical engineers. The number of workers with the firm still fluctuates significantly based on market demand.

57. Liberalization of trading rights has led to a significant increase of private enterprises active in international trade. The number of non-state enterprises engaged in trade grew from 1,785 in 1998 to almost 7,000 in 2000. It is not clear whether this represents an increase in private sector intermediaries and traders or an increase in the number of private enterprises active in export-oriented manufacturing industries. Either case is encouraging, either for the direct increase in the export-oriented manufacturing sector or for the increase in competition among firms servicing those same exportoriented manufacturers. 
Table 5.7 Enterprises Engaged in International Trade *

\begin{tabular}{lcccr}
\hline & July 1998 & \multicolumn{3}{c}{ May 2000 } \\
\hline Total Enterprises & Number & Share & Number & Share \\
State Owned & $\mathbf{5 1 0 0}$ & $\mathbf{1 0 0 \%}$ & $\mathbf{1 1 0 5 9}$ & $\mathbf{1 0 0 \%}$ \\
Foreign Invested & 1938 & $38 \%$ & 2544 & $23 \%$ \\
Domestic Non-state & 1377 & $27 \%$ & 1548 & $14 \%$ \\
Source: General Department of Customs, 2001 & * Counts of firms engaged in trade are only \\
made at certain times during the year. & \multicolumn{4}{l}{}
\end{tabular}

58. Total export revenues in the domestic non-state sector have also grown much faster than SOEs in the past few years. Between 1998 and 2000, exports by domestic non-state companies more than doubled, while exports by SOEs grew only 4.5 percent. More than 90 percent of export growth appears to have been due to private enterprises and more than 40 percent entirely to the domestic private sector.

Table $5.8 \quad$ Non-oil Export Growth by Enterprise Type

\begin{tabular}{lrrrr}
\hline & $\begin{array}{r}\mathbf{1 9 9 8} \\
\text { (USD Mn) }\end{array}$ & $\begin{array}{r}\mathbf{2 0 0 0} \\
\text { (USD Mn) }\end{array}$ & $\begin{array}{r}\text { 2 Year Export } \\
\text { Growth(\%) }\end{array}$ & $\begin{array}{r}\text { Share in Export } \\
\text { Growth (\%) }\end{array}$ \\
\hline State Owned Enterprises & & & & \\
Foreign Invested Enterprises & 5,073 & 5,255 & 4.7 & 8.5 \\
Domestic Non-State Enterprises & 1,983 & 3,308 & 67.8 & 47.7 \\
& 1,072 & 2,384 & 115.1 & 43.8 \\
Total & $\mathbf{8 , 1 2 8}$ & $\mathbf{1 0 , 9 4 7}$ & $\mathbf{3 4 . 7}$ & $\mathbf{1 0 0 . 0}$ \\
\hline
\end{tabular}

Source: General Department of Customs and Ministry of Trade 2000, World Bank, 2001

59. Private sector output in labor-intensive manufacturing industries is growing strongly. Between 1995 and 1999, the formal private sector contributed nearly 15 percent to total manufacturing growth, quite a substantial contribution given the relative size of the sector. The share of private manufacturing output in total output increased 25 percent (from $8 \%$ to $10.3 \%$ ). Manufacturing output per worker in 1999 stood at 44 Million VND. 
Table 5.9 Manufacturing Output Growth

\begin{tabular}{|c|c|c|c|c|c|}
\hline & $\begin{array}{r}1995 \\
\text { Output } \\
\text { (Bil VND) }\end{array}$ & $\begin{array}{r}1999 \\
\text { Output } \\
\text { (Bil VND) }\end{array}$ & $\begin{array}{r}1999 \\
\begin{array}{r}\text { Output/Worker } \\
\text { (Mil VND) }\end{array}\end{array}$ & $\begin{array}{l}5 \text { year } \\
\text { growth }\end{array}$ & $\begin{array}{r}\text { Contribution } \\
\text { of the formal } \\
\text { private sector } \\
\text { to growth }\end{array}$ \\
\hline $\begin{array}{l}\text { Manufacturing } \\
\text { Of which }\end{array}$ & $83,260.5$ & $133,702.4$ & 44 & $60.6 \%$ & $14.3 \%$ \\
\hline $\begin{array}{l}\text { Food \& } \\
\text { Beverage }\end{array}$ & $27,008.2$ & 40269.8 & 68 & $49.1 \%$ & $16.0 \%$ \\
\hline Textiles & 6176.2 & 9254.9 & 43 & $49.8 \%$ & $14.8 \%$ \\
\hline Garments & 2949.8 & 5210.7 & 17 & $76.6 \%$ & $24.6 \%$ \\
\hline Leather & 3569.9 & 8179.7 & 20 & $129.1 \%$ & $20.1 \%$ \\
\hline $\begin{array}{l}\text { Paper \& Paper } \\
\text { Products }\end{array}$ & 1946.8 & 3520.3 & 59 & $80.8 \%$ & $28.6 \%$ \\
\hline $\begin{array}{l}\text { Rubber \& } \\
\text { Plastics }\end{array}$ & 2272 & 4960.7 & 129 & $118.3 \%$ & $36.7 \%$ \\
\hline Metal Products & 2331.6 & 4715.5 & 441 & $102.2 \%$ & $19.1 \%$ \\
\hline
\end{tabular}

Source: GSO, 2001

60. Overall, from 1998 to 2000 , the share of private companies in manufacturing fell slightly, but the percentage of private sector workers in manufacturing rose from 53 percent to 57 percent. Employment in the crucial food and beverage processing sector increased over the same period by 54 percent, despite a fall in the total number of companies. The result was an increase in per firm employment from 20 workers to 32 . Other benchmark sectors for judging Vietnam's reliance on labor-intensive, exportoriented activities are textiles, garments, and leather goods and all three showed impressive growth over the two year period. GSO output statistics now show the private sector to be ahead of the state sector in garments and in leather shoe production.

Table 5.10 1998-2000 Growth in Labor Intensive Manufacturing (\%)

\begin{tabular}{lll}
\hline & Increase in Firms & Increase in Employment \\
\hline Food and Beverage Processing & -5 & 54 \\
Textiles & 65 & 92 \\
Garments & 44 & 40 \\
Leather Products & 68 & 24 \\
\hline
\end{tabular}

Source: GSO, 2001

61. But Vietnam still has a relatively large untapped potential to expand its activities in labor intensive and export-oriented manufacturing industries. A study of Vietnam's export oriented industries showed that-compared with other Asian nationsmanufacturers accounted for only a relatively small share (36.4\%) of exports in 1997. Given its high human capital and its large supply of labor relative to land Vietnam could significantly raise its labor-intensive manufacturing exports. The study predicts that, with more efficient use of available resources, Vietnam could be expected to increase its share of labor-intensive manufacturers in total exports by 25 percent. $^{36}$ Even though exports surged in recent years, the share of manufacturing in total exports in 2000 still stands roughly at the same level (36.4\%).

\footnotetext{
${ }^{36}$ Belser (1999). Vietnam. On the Road to Labor-Intensive Growth.
} 


\section{OBSTACLES TO PRIVATE SECTOR GROWTH}

62. A continued growth of the formal private sector and its contribution to employment generation in the coming decade will ultimately depend on the extent to which existing barriers to private sector activities are removed. But removing barriers will not be enough; the government will need to establish an enabling and supportive environment for private enterprise.

\section{Main Obstacles Identified in Earlier Studies}

63. A number of studies have looked at constraints to private sector development. ${ }^{37}$ Analysts seem to be broadly in agreement about the following five cons traints. ${ }^{38}$

- Institutional weaknesses. Vietnam is in the process of a transition from a centrally planned to a market economy. At present, however the institutional framework to support this newly emerging market economy does not exist, is incomplete or is ineffective. Regularly mentioned institutional barriers are complicated entry and exit procedures, tax regulations, trade barriers, regulations on land markets, and unequal treatment of SMEs (compared to SOEs). In the past few years, the government has taken a number of measures to address these issues. Perhaps the most important measure so far was the introduction of the Enterprise Law. Some analysts have argued however that many new measures have been ineffective due to a lack of sound implementation procedures. Also as barriers to enterprise development are being removed, more attention needs to be given to positive ways of supporting private sector development. At this stage, for example, institutions supporting market transactions, such as contract laws and contract enforcement mechanisms, are weak or non-existent.

- Capital shortage. Even though credit flows to the non-state sector have increased in recent years, capital is still considered a major constraint to private sector development. The shortage of bank credit is based on both supply and demand side constraints. Banks resist making loans to private enterprises for several reasons. It is hard for bankers to conduct a good risk appraisal -due to lack of training and experience- and even if the risk is assessed accurately, bankers have not been able to price the risk into their loans due to restrictions in interest rates. Lack of incentives for bank officers at state banks to take initiative or calculated risks is also a problem for non-traditional borrowers like newly established SMEs. Lack of collateral and the absence of an effective bankruptcy law cause private SMEs further troubles. On the demand side, some analysts claim that private enterprises are reluctant to access bank credit because the procedures require a high level of transparency with respect to their business activities.

- Limited access to markets. The lack of knowledge about and the limited access to markets has left many enterprises competing for a fairly small often local market. Moreover, Vietnamese enterprises have often poor quality and low value adding products which make it hard to compete in international markets.

\footnotetext{
37 The most comprehensive studies include MPI-UNIDO (1999), Mallon (1997 and 1999), Riedel et al. (1997) and Riedel (1999), Webster \& Taussig (1999) and Webster (1999).

${ }^{38}$ Le Cong Luyen Viet (2001).
} 
- Technical and management limitations. Webster et al. (1998) stress more than any other study the importance of modern technology and skills for both managers and workers.

- Public attitudes. A 1999 survey carried out by MPDF revealed how the public opinion toward private enterprises is highly negative ${ }^{39}$. According to private sector analysts there is a need for a shift from an attitude of reluctance and control to one of active support and encouragement.

\section{Are Key Obstacles to Further Private Sector Development Changing?}

64. In the past few years the government took a number of steps to reduce the constraints to business activities in Vietnam and create a more conducive environment for private enterprise. The question is however whether these measures have led to real changes in perceived business obstacles. In this survey enterprises were asked to list the three most important obstacles to their business development. The results were compared with the reported obstacles in the 1997 NIAS-survey in order to identify changes in perceptions over the past few years ${ }^{40}$.

65. The broad nature of the obstacles to private sector development has remained more or less the same but there seems to be a shift in the relative importance of certain obstacles. Table 6.1 compares the reported main obstacle in both surveys.

66. Capital remains the most important constraint for more than one third of the enterprises. Market constraints (limited market demand and too much competition) were reported as the main constraint by more than 30 percent of the respondents. The relative importance of this constraint has fallen, though, in comparison with previous years. There could be several reasons for this:

- Trade liberalization. The freeing up of trading rights for domestic private companies in the late 90s (Decree 57/CP) gave private companies direct access to foreign markets. Other commitments related to Vietnam's entrance in bilateral, regional and multi-lateral agreements may also have resulted in greater access to markets.

- Increased purchasing power of consumers in the domestic market.

- Level playing field. In its efforts to promote private sector development the government has taken a number of measures to level the playing field between private and state enterprises. This may have led to a more fair access to markets for domestic private companies.

\footnotetext{
${ }^{39}$ MPDF (1999). Report on Survey of Attitudes toward the Private Sector in Vietnam.

${ }^{40}$ The NIAS survey was carried out with small private manufacturers $(<100$ employees) in 5 provinces (Hanoi, Ha Tay, Haiphong, Ho Chi Minh and Long An). The results of the 1997 survey were compared with a subset of our survey. For the purpose of comparison we only analyzed the obstacles for the small manufacturing companies in the sample.
} 
Table 6.1 Main Constraint to Business Development (\%)

\begin{tabular}{|c|c|c|c|c|}
\hline \multirow[t]{2}{*}{ Obstacles } & \multicolumn{2}{|c|}{1997 Survey } & \multicolumn{2}{|c|}{2001 Survey } \\
\hline & $\begin{array}{r}\text { Sole } \\
\text { Proprietorship }\end{array}$ & $\begin{array}{r}\text { Limited } \\
\text { Liability \& } \\
\text { Shareholding }\end{array}$ & $\begin{array}{r}\text { Sole } \\
\text { Proprietorship }\end{array}$ & $\begin{array}{r}\text { Limited } \\
\text { Liability \& } \\
\text { Shareholding }\end{array}$ \\
\hline Insufficient Capital & 31.8 & 32.5 & 35.7 & 39.5 \\
\hline $\begin{array}{l}\text { Insufficient skilled } \\
\text { workers }\end{array}$ & 1.5 & 0.0 & 4.8 & 10.5 \\
\hline $\begin{array}{l}\text { Insufficient } \\
\text { technical know-how }\end{array}$ & 0.0 & 0.0 & 0.0 & 1.3 \\
\hline $\begin{array}{l}\text { Limited market } \\
\text { demand/too much } \\
\text { competition }\end{array}$ & 48.4 & 44.2 & 35.7 & 27.6 \\
\hline $\begin{array}{l}\text { Lack of } \\
\text { marketing/transport }\end{array}$ & 3.0 & 1.3 & 4.8 & 1.3 \\
\hline $\begin{array}{l}\text { Lack of modern } \\
\text { machinery }\end{array}$ & 0.0 & 3.9 & 4.8 & 2.6 \\
\hline Lack of raw material & 0.0 & 2.6 & 2.4 & \\
\hline $\begin{array}{l}\text { Too much } \\
\text { interference by local } \\
\text { officials }\end{array}$ & 0.0 & 1.3 & 0.0 & 1.3 \\
\hline $\begin{array}{l}\text { Unstable policy } \\
\text { environment }\end{array}$ & 1.5 & 5.2 & 0.0 & 2.6 \\
\hline $\begin{array}{l}\text { Insufficient land } \\
\text { space }\end{array}$ & 6.1 & 1.3 & 9.5 & 10.5 \\
\hline Other & 4.5 & 2.5 & 2.4 & 0.0 \\
\hline No problems & 3.0 & 5.2 & 0.0 & 2.6 \\
\hline Total & 100 & 100 & 100 & 100 \\
\hline
\end{tabular}

Source: World Bank Survey, 2001 \& Ronnas et al., 2001

67. Two obstacles that became more important over the last few years are access to land and skilled labor. The increased need for more land is most likely a sign of the growing size and maturation of private companies. Small and Medium Enterprises are growing into larger enterprises. The need for land is also related however to the increased need for capital as land use rights are often required as collateral for bank loans.

68. The lack of skilled labor has become relatively more important as constraint for private enterprises, more in the South than in the North. Even though the general educational level of Vietnam's labor force is relatively high-in 2000, the rate of illiteracy and uncompleted primary education stood only at $20.5 \%$ - there is a lack of technically skilled labor ${ }^{41}$. The lack of skilled workers in the manufacturing sector was also confirmed in the case studies.

${ }^{41}$ MOLISA. Labor Survey 2000. 


\section{Box 6.1 Dung Cam Company: Braving a Difficult Environment for Growth}

Dung Cam Company began operations as a machinery engineering business in the early 1990s with 14 workers. Today Dung Cam employs 320 workers. A new factory producing plastic molds for car doors will further increase the company's work force to 500 within the next year, and a further 600 additional jobs will be created in 2005 when the company plans to begin production of certain car and motorcycle parts.

Dung Cam's growth is particularly impressive considering the tough business environment for machinery companies in the North. The machinery engineering sector is dominated by large state firms saddled with fairly outdated equipment, yet able to operate relatively unencumbered by pressure to keep their balance sheets out of the red. Accessing finance has also proven a difficult task, despite Dung Cam's impressive revenue flows and clear business plans. The only loans banks have been willing to extend have been very short-term. Mr. Tran Thang, the owner of Dung Cam Co., says he has been hesitant to try to get capital from the government's Development Support fund for Domestic Private Companies because of a fear that any loan would come accompanied by a significant increase in inspections and other visits from local authorities that, in the end, would prove too costly.

The biggest obstacle to growth for Dung Cam, however, has been land management by local government. Mr. Thang first approached city officials with plans to build a factory producing plastic molds for car doors in 1993, but officials informed him the city had not yet formulated its own official plan for use of that plot of land and therefore could not approve any new initiatives. In 1997, the company decided to move forward with construction without permission but was forced to stop by local officials who still had not drawn up a plan. Finally in 2001, Dung Cam Co. was informed approval would come in 2002 and that construction could commence. According to Mr. Thang, Dung Cam is just one of numerous private firms that have had investment plans stalled due to lack of a local level city plan. State enterprises, he says, are not affected by this issue, as they are able to get appropriate land on demand. Foreign firms also get more timely approval for land use and, if not, can usually afford to buy space in Vietnam's costly industrial zones.

69. About one third of the companies interviewed had difficulties finding shop floor workers and about one quarter experienced limitations hiring management workers. The chief limitation for these companies was finding quality workers both at the workers and management level. For about 15 percent of the companies problems in hiring labor were caused by the bad reputation of the private sector. Another 10 percent would cite high costs as an impediment to hiring more workers 
Box 6.2 Kinh Nghiem Joint Stock Company and Dao Tao Ltd.: Private Sector Solutions to Private Sector Problems

Kinh Nghiem Joint Stock Company is a large private shoe manufacturer located on the outskirts of Hanoi. About 80 percent of Kinh Nghiem Joint Stock Co.'s 1,600 employees have come to the capital from the countryside specifically to work for the company. Workers are generally educated at most to the high school level and have limited job experience, so training is very important and time consuming. State-run training schools do not offer suitable courses on shoe manufacturing, so training must take place on-site at the factory. Kinh Nghiem's recent move up the value-added chain from CMT (cut-make-trim) production-where workers piece together imported, pre-cut materials - to more comprehensive, more profitable FOB (freight-on-board) production-where the company sources its own raw materials and workers must do initial cutting in addition to piecing together-has increased the company's need for skilled workers dramatically, and with it the importance of high quality worker training.

After numerous years of negotiation with local officials, the owners of Kinh Nghiem were this year able to secure the rights to land adjacent to their existing factory. Kinh Nghiem's owners have decided to use this land not only for additional factory space and living quarters, but also for housing something highly unusual in Vietnam: an on-site training center. The training center is being set up as a separately-owned business, Dao Tao, Ltd,. with its own separate financial statements. The training center aims to provide not only high quality training to meet Kinh Nghiem's FOB training needs, but to also develop a reputation for these services that will allow it to win bids to train workers for other shoe manufacturers in the area. Dao Tao's owner, Mr. Nguyen Giao Duc, expects his firm to be a model for the profitability of investing into trainingaiming not only to increase the skills of workers, but to also raise the professionalism of the entire sector.

.Table 6.2 Chief Limitation on Firm's Ability to Hire Workers (\%)

\begin{tabular}{lcrrr}
\hline & \multicolumn{2}{c}{ Industries } & \multicolumn{2}{r}{ Total } \\
\hline & Manufacturing & & Other industry & Services \\
Difficult to find quality workers & 70.6 & 50.0 & 80.7 & 73.0 \\
Bad reputation of private sector among & 11.8 & 16.7 & 17.5 & 14.6 \\
workers & & & & \\
High costs of labor & 10.3 & 16.7 & & 6.6 \\
High costs associated with hiring more & 7.4 & & 1.8 & 4.4 \\
workers & & & & \\
Other & & 16.7 & & 1.5 \\
Total & $\mathbf{1 0 0 . 0}$ & $\mathbf{1 0 0 . 0}$ & $\mathbf{1 0 0 . 0}$ & $\mathbf{1 0 0 . 0}$ \\
\hline
\end{tabular}

Source: World Bank Survey, 2001

70. Limitations in the hiring process are partly caused by the informal mechanisms used in recruiting labor. Over 60 percent of workers are hired through word of mouth through friends, family or existing employees. Only about 14 percent of workers are hired through advertisements in the newspaper. 
Table 6.3 Main Means of Hiring Workers (\%)

\begin{tabular}{lrrrr}
\hline & Manufacturing Other industry & Services & Total \\
\hline Advertisement in mass media & 12.3 & 9.1 & 16.4 & 14.2 \\
Post announcement outside factory gate & 9.7 & 9.1 & .5 & 4.7 \\
Through a training center & 5.8 & 9.1 & 5.2 & 5.7 \\
Through Labor Service Center & 11.6 & 15.2 & 12.2 & 12.2 \\
Through Management Board of EPZ/IPZ & 0.6 & & 0.5 & 0.5 \\
Word of mouth through existing & 24.5 & 24.2 & 15.0 & 19.5 \\
employees & & & & \\
Word of mouth through friends and & 34.8 & 33.3 & 49.3 & 42.4 \\
family & & & & \\
Other & .6 & & 1.0 & .7 \\
Total & $\mathbf{1 0 0 . 0}$ & $\mathbf{1 0 0 . 0}$ & $\mathbf{1 0 0 . 0}$ & $\mathbf{1 0 0 . 0}$ \\
\hline Sour
\end{tabular}

Source: World Bank Survey, 2001

\section{Conditions for Expansion in the Next 12 Months}

71. The survey also explored whether companies had plans for expansion in the next 12 months. About 37 percent reported they had definite plans for expansion and another 24 percent said they might expand if certain conditions would be fulfilled. The most important condition for expansion mentioned by almost 50 percent of the respondents was gaining access to new markets, 24 percent mentioned access to land as the main condition and another 17 percent said their expansion would be dependent on getting access to commercial financing.

Table 6.4 Main Condition for Expanding Labor Force (\%)

\begin{tabular}{lrrrr}
\hline & $\begin{array}{r}\text { Industries } \\
\text { Manufacturing }\end{array}$ & $\begin{array}{r}\text { Other } \\
\text { industry }\end{array}$ & Services & Total \\
\hline Bilateral Trade Agreement with the US & 2.7 & 0.0 & 0.0 & 1.0 \\
implemented & & & & \\
Able to access new market & 43.2 & 72.7 & 47.9 & 49.0 \\
Able to access commercial financing & 16.2 & 9.1 & 18.8 & 16.7 \\
Able to again access to more land & 27.0 & 18.2 & 22.9 & 24.0 \\
Able to access benefits of specific & 8.1 & 0.0 & 6.3 & 6.3 \\
favorable government policy & & & & \\
Other & 2.7 & 0.0 & 4.2 & 3.1 \\
Total & $\mathbf{1 0 0 . 0}$ & $\mathbf{1 0 0 . 0}$ & $\mathbf{1 0 0 . 0}$ & $\mathbf{1 0 0 . 0}$ \\
\hline Sourc: Survey, & & & &
\end{tabular}

Source: Survey, 2001 


\section{REFERENCES}

Bales, Sarah (2000). Vietnam's Labor Situation and Trends: Analysis based on the 199293 and 1997-98 Vietnam Living Standard Surveys. Background Paper for the Vietnam Development Report 2000.

Belser, Patrick (1999). Vietnam: On the Road to Labor-Intensive Growth? Background Paper for the Vietnam Development Report 2000.

CIEM/UNDP (2001). Domestic Private Sector Update. Improving Business Regulations and Regulatory Processes. Hanoi

GSO (2001). Statistical Yearbook. Statistical Publishing House, Hanoi.

Le Cong Luyen Viet (2001). Small and Medium Enterprises in Vietnam : In Search of the Actual Obstacles to Growth. The National University of Singapore, Master Thesis.

MOLISA (2001). Status of Labor - Employment in Vietnam. Labor and Social Affairs Publishing House.

MPI-UNIDO (1999). Improving Macro-Economic Policy and Reforming Administrative Procedures to Promote Development of Small and Medium Enterprises in Vietnam. US/VIE/95/004.

Riedel, James \& Chuong Tran (1997). The Emerging Private Sector and the Industrialization in Vietnam. Private Sector Discussions. MPDF, Hanoi.

Ronnas, Per \& Bhargavi Ramamurthy (Eds.) (2001). Entrepreneurship in Vietnam. Transformation and Dynamics. NIAS Publishing, Copenhagen.

Steer, Liesbet (2001). The Private Sector in Vietnam. Facts, Figures, Policy Changes and a Survey of Research Findings. Centre for International Economics, Canberra.

Webster, Leila \& Markus Taussig (1999). Vietnam's Undersized Engine. A Survey of 95 Large Private Manufacturers. Private Sector Discussions. MPDF, Hanoi

Webster, Leila (1999). SMEs in Vietnam. On the Road to Prosperity. Private Sector Discussion Series, MPDF, Hanoi. 